NBER WORKING PAPER SERIES

\title{
SOVEREIGN DEBT PORTFOLIOS, BOND RISKS, AND THE CREDIBILITY OF MONETARY POLICY
}

\author{
Wenxin Du \\ Carolin E. Pflueger \\ Jesse Schreger \\ Working Paper 22592 \\ http://www.nber.org/papers/w22592
}

\author{
NATIONAL BUREAU OF ECONOMIC RESEARCH \\ 1050 Massachusetts Avenue \\ Cambridge, MA 02138 \\ September 2016
}

\begin{abstract}
We are grateful to Mark Aguiar, Daniel Andrei, Adrien Auclert (discussant), John Campbell, Lorenzo Garlappi, Joshua Gottlieb, Juan Carlos Hatchondo (discussant), Tarek Hassan, Oleg Itskhoki, Thomas Mertens, Vincenzo Quadrini (discussant), Julio Rotemberg, Rosen Valchev (discussant), Adrien Verdelhan, Jenny Tang, Pierre Yared, and seminar participants at AEA 2016, UCLA Anderson, Columbia University, Stanford GSB, MIT Sloan, the 8th Macro-Society Meeting, NBER Summer Institute, UC Santa Barbara, the San Francisco Federal Reserve, the Federal Reserve Bank of Chicago, the Bank for International Settlements, and the University of British Columbia for helpful comments. Jiri Knesl, Sandra Ramirez, George Vojta, and Nanyu Chen provided excellent research assistance. Pflueger thanks MIT Sloan and Stanford GSB for their hospitality and UBC for research funding while working on this research. Schreger thanks the Princeton Economics Department for their hospitality during the research process and the Harvard Business School Division of Research for financial support. The views expressed herein are those of the authors and do not necessarily reflect the views of the National Bureau of Economic Research.
\end{abstract}

At least one co-author has disclosed a financial relationship of potential relevance for this research. Further information is available online at http://www.nber.org/papers/w22592.ack

NBER working papers are circulated for discussion and comment purposes. They have not been peerreviewed or been subject to the review by the NBER Board of Directors that accompanies official NBER publications.

(C) 2016 by Wenxin Du, Carolin E. Pflueger, and Jesse Schreger. All rights reserved. Short sections of text, not to exceed two paragraphs, may be quoted without explicit permission provided that full credit, including $\odot$ notice, is given to the source. 
Sovereign Debt Portfolios, Bond Risks, and the Credibility of Monetary Policy

Wenxin Du, Carolin E. Pflueger, and Jesse Schreger

NBER Working Paper No. 22592

September 2016, Revised August 2019

JEL No. E4,F3,G12,G15

\section{ABSTRACT}

We document that governments whose local currency debt provides them with greater hedging benefits actually borrow more in foreign currency. We introduce two features into a government's debt portfolio choice problem to explain this finding: risk-averse lenders and lack of monetary policy commitment. A government without commitment chooses excessively counter-cyclical inflation ex post, which leads risk-averse lenders to require a risk premium ex ante. This makes local currency debt too expensive from the government's perspective and thereby discourages the government from borrowing in its own currency.

Wenxin Du

Booth School of Business

University of Chicago

5807 S. Woodlawn Avenue

Chicago, IL 60637

and NBER

Wenxin.Du@chicagobooth.edu

Carolin E. Pflueger

University of Chicago

Harris School of Public Policy

1307 E 60th St

Chicago, IL 60637

and NBER

cpflueger@uchicago.edu
Jesse Schreger

Columbia Business School

3022 Broadway

Uris Hall 821

New York, NY 10027

and NBER

jesse.schreger@columbia.edu

A online appendix is available at http://www.nber.org/data-appendix/w22592 


\section{Introduction}

How should governments finance their deficits? A long-standing literature argues that governments should borrow using state-contingent debt to smooth fluctuations in domestic consumption or tax rates (for instance, Barro (1979); Bohn (1990a,b); Calvo and Guidotti (1993); Barro (2003); Lustig et al. (2008)). Debt that is denominated in a country's own currency is thought to help achieve this desired state-contingency, because the government can vary inflation to reduce the real debt burden in bad times.

In this paper, we demonstrate empirically that governments whose local currency (LC) debt provides them with greater hedging benefits actually borrow relatively more in foreign currency (FC). This relationship is puzzling from the perspective of the theory of optimal government debt issuance. We explain it by adding two features to an otherwise standard debt portfolio choice model: risk-averse lenders and lack of inflation commitment. If international lenders are risk-averse and global and domestic output are correlated, lenders will require a risk premium for holding debt that pays off poorly in domestic downturns. In our model, a government that cannot commit to an inflation policy rule ex ante will use counter-cyclical inflation ex post to smooth domestic consumption more than is optimal. As a result, lenders charge governments without commitment a risk premium on their LC debt, and these governments face a strong incentive to borrow in FC debt instead in order to lower their expected borrowing costs.

We start by investigating empirically whether governments that borrow in LC debt actually use that debt to smooth domestic consumption. Our sample is determined by the availability of long-term LC bond return data and comprises 11 developed markets and 17 emerging markets over the period 2005-2014. We measure the hedging properties of LC debt for the domestic borrower with the regression beta of LC bond excess returns on local stock market excess returns. ${ }^{2}$ We refer to this measure as the bond-stock beta. We estimate a significant degree of cross-country heterogeneity in bond-stock betas. If LC bonds tend to fall in value at the same time as the local stock market, then the bond-stock beta will be positive. In that case, LC debt loses value exactly when a reduction in debt is most valuable to the borrowing government, thereby insuring the borrower against economic downturns. Therefore, if governments borrow with LC debt to take advantage of the domestic smooth-

\footnotetext{
${ }^{2}$ Here, the domestic stock market serves as a proxy for domestic consumers' stochastic discount factor. If there is a benevolent government and a representative consumer, as in our model, the government's and consumer's stochastic discount factor will coincide.
} 
ing benefits traditionally emphasized in the literature, we should find a positive relationship between a country's bond-stock beta and its LC debt share. By contrast, we find a strong negative relationship between the LC share in government debt and a country's bond-stock beta. This pattern holds for the currency composition of total sovereign debt, as well as three measures of the currency composition of external sovereign debt held by international investors.

We next provide evidence that the cyclicality of LC bond returns is driven by macroeconomic dynamics and, in particular, the cyclicality of inflation expectations. If the real burden of LC debt is indeed state-contingent due to inflation variability, LC bond returns should move inversely with inflation expectations. This logic suggests that countries with the lowest bond-stock betas should have the highest betas of inflation expectations with respect to the business cycle. We confirm this prediction in the data, measuring the cyclicality of inflation expectations using the beta of long-term inflation forecasts with respect to long-term output growth forecasts from Consensus Economics. This finding is robust to using the beta of realized inflation with respect to realized industrial production instead of survey expectations for inflation and output.

Two pieces of evidence demonstrate that the LC bonds with the best hedging value for the borrowing government are also the riskiest for international lenders. First, the bonds with the highest beta with respect to the local stock market also have the highest beta with respect to the US stock market. Second, international lenders expect to be compensated for bearing this risk, as captured by higher LC bond risk premia. In addition, we show that cross-country differences in LC bond risks are correlated with the governments' inflation credibility, based on a text-based measure from newspaper word counts. These links provide the empirical motivation for our model, where the ability to commit to an inflation policy function drives both the cyclicality of inflation and the LC bond risk premium, and therefore the equilibrium choice of the currency composition of debt.

We present a two-period model to explain the relationship between the choice of borrowing currency and the hedging properties of LC debt documented in the data. We consider two types of governments - one that can commit to a future inflation policy and one that cannot. The ability to commit is an exogenous characteristic of the government. Both the currency composition of government debt and the hedging value of LC debt are endogenous and chosen optimally by the government. Crucially, debt is priced by risk-averse lenders, whose stochastic discount factor (SDF) is assumed to be correlated with domestic output. A government with commitment sets its inflation policy as a function of domestic output, before domestic output is realized, and before its debt is priced and sold to international lenders. Such a government balances its desire to smooth domestic consumption against the 
risk premium lenders will charge it for inflating more in bad times. By contrast, a government that lacks commitment and operates under discretion chooses inflation after the debt has been priced and sold and after observing the state of the domestic economy.

The model has two key results. First, governments without commitment choose more counter-cylical inflation than governments with commitment for a given LC debt share. This is because governments without commitment do not internalize the effect of their countercyclical inflation policy on the LC bond risk premium. To show this, we characterize the inflation policy functions of the two types of governments analytically by log-linearizing their first-order conditions in a simplified special case. Second, governments without commitment tilt their borrowing towards FC debt. They do so in order to reduce their expected borrowing costs arising from the $\mathrm{LC}$ bond risk premium. FC debt also acts as a commitment device to limit the government's own incentive to generate counter-cyclical inflation in the future, thereby lowering the LC bond risk premium ex ante. ${ }^{3}$

We then demonstrate that this mechanism can quantitatively explain the empirical patterns. We calibrate the model twice, once for a government with commitment ("Developed Markets") and once for governments without commitment ("Emerging Markets"). These differences in credibility can generate the empirically observed cross-country relationship between bond cyclicality and the currency composition of sovereign debt. With risk-neutral lenders, however, the model cannot generate the negative relationship between LC bondstock betas and LC debt shares that we see in the data. This is because when international lenders do not charge a risk premium for insuring domestic consumption risk, the ability to commit affects only the average level but not the cyclicality of inflation. The qualitative relationship between LC bond-stock betas and LC debt shares is not sensitive to the value of the international risk aversion parameter, provided that it is greater than zero. Quantitatively, a relatively high degree of international risk aversion is required to match the level of the LC bond risk premium and the LC debt share in DMs and EMs.

This paper contributes to the extensive literature on optimal government debt management by showing that bond risk premia are a powerful driver of LC debt issuance across countries. The standard result in this long-standing literature prescribes that governments borrow with state-contingent debt that lowers debt repayments in recessions (Barro, 1979; Lucas and Stokey, 1983; Bohn, 1988, 1990b), in contrast to the patterns we document in the

\footnotetext{
${ }^{3}$ Separately from the implications for inflation cyclicality, a lack of commitment also leads to higher inflation on average in our model.
} 
data. $^{4}$

This paper also contributes to the literature on "original sin" (Eichengreen and Hausmann 1999, 2005), the tendency of emerging market governments to borrow from international lenders in foreign currency. Du and Schreger (2016b), Ottonello and Perez (2019), and Engel and Park (2018) examine the shift of emerging market governments towards borrowing in their own currency. The prior theoretical literature linking debt levels and inflation argues that a lack of commitment leads to inflation that is too high on average (Bohn, 1988; Calvo and Guidotti, 1990; Missale and Blanchard, 1994; Barro, 2003; Alfaro and Kanczuk, 2010; Díaz-Giménez et al., 2008). However, a model where a lack of commitment affects only the average inflation level and not its cyclicality cannot explain why the hedging properties of LC debt vary across countries as we see in the data. We emphasize the cyclicality of inflation, which is what drives LC bond risk premia and hence raises the real cost of borrowing in LC.

We also contribute to the international asset pricing literature. A growing literature has argued that international bond and currency risk premia depend on the comovement of returns with a priced factor, and, in particular, international lenders' consumption stream (Harvey, 1991; Colacito and Croce, 2011, 2013; Karolyi and Stulz, 2003; Lustig and Verdelhan, 2007; Lewis, 2011; Borri and Verdelhan, 2011; Lustig et al., 2011; David et al., 2016; Della Corte et al., 2016; Xu, 2019). We show that these risk premia have real effects on government fiscal policy. Similarly to Hassan (2013) and Hassan et al. (2016), we argue that government bond yields reflect the insurance value for lenders, even though the source of comovement that we focus on - monetary policy credibility - is different.

Finally, we contribute to a recent literature on time-varying bond risks (Baele et al. (2010); David and Veronesi (2013); Campbell et al. (2017); Ermolov (2018); Duffee (2018); Campbell et al. (2019)), which is primarily focused on the US and the UK. Different from those papers, we focus on cross-country patterns in bond-stock correlations.

The structure of the paper is as follows: In Section 2, we present new stylized facts on the relationship between the hedging properties of LC bonds and shares of LC debt in sovereign portfolios. In Sections 3 and 4, we lay out the model, provide analytical intuition for the key mechanisms, and calibrate the model to demonstrate that it can replicate the observed patterns of the currency composition of sovereign debt and LC bond risks. Section 5 concludes.

\footnotetext{
${ }^{4}$ The existing literature that features risk-averse lenders does not tackle the problem of the currency composition of debt portfolios. For example, Lustig et al. (2008) study nominal debt issuance with perfect commitment in the domestic context, Debortoli et al. (2017) examine the optimal maturity structure of real government debt, and Broner et al. (2013) study the maturity choice of FC debt issuance.
} 


\section{Empirical Relation Between Local Currency Bond Risks and Local Currency Debt Shares}

We first document that the hedging properties of LC bonds show economically and statistically significant variation across countries. We then investigate empirically whether countries where LC debt offers greater hedging benefits for the domestic borrower choose to have more of it, as prescribed by standard theory of optimal government debt. In contrast to this intuition, we present robust empirical evidence that countries with the lowest LC debt shares also have the most pro-cyclical LC bond returns. In other words, the countries who rely on LC debt the least actually have the LC bonds that offer the best consumption-smoothing benefits to the borrower.

\subsection{Measuring Cyclicality of Nominal Risk and LC Debt Shares}

We examine a cross-section of countries as permitted by the availability of long-term LC debt data. We include 11 developed markets (Australia, Canada, Denmark, Germany, Japan, New Zealand, Norway, Sweden, Switzerland, the United States, and the United Kingdom) and 17 emerging markets (Brazil, Chile, Colombia, the Czech Republic, Hungary, Indonesia, Israel, Malaysia, Mexico, Peru, Philippines, Poland, Singapore, South Africa, South Korea, Thailand, and Turkey). ${ }^{5}$ We exclude developed markets in the euro area, except for Germany, due to the lack of independent monetary policy. We exclude China, India and Russia due to restrictions on foreign holdings of LC government debt for a large part of our sample. Because for most emerging markets in our sample LC government bond curves are available starting in the mid-2000s, our sample covers the period 2005-2014 to maintain a balanced panel. ${ }^{6}$

Since our cross-country sample is constrained by the availability of long-term LC bond markets, we naturally have a limited number of sample countries that constrains our crosscountry analysis. However, our cross-country sample represents an improvement over much of the existing literature on sovereign debt, which has focused on a subset of our sample countries and examined emerging and developed markets separately. The larger cross-country

\footnotetext{
${ }^{5}$ We provide a list of local currency names and three-letter currency codes for our sample countries in Appendix A.1.

${ }^{6}$ For LC bond yields, we primarily use Bloomberg fair value (BFV) curves. We use the five-year tenor, which has the most consistent data availability across a wide range of countries. BFV curves are estimated using individual LC sovereign bond prices traded in secondary markets. Since sufficient numbers of bonds spanning different maturities are needed for yield curve estimation, the availability of the BFV curve is a good indicator for the overall development of the LC nominal bond market. Countries such as Argentina, Uruguay, and Venezuela have only a handful of fixed-rate bonds and hence do not have a BFV curve.
} 
sample allows us to provide the first systematic treatment of cross-country differences in LC bonds' hedging properties.

We use three empirical approaches to measure the hedging value of LC bonds from the perspective of the domestic borrower. First, we use betas of LC bond returns with respect to the domestic stock market. Here, the domestic stock market serves as a proxy for domestic consumers' stochastic discount factor (SDF). Under the assumptions of a benevolent government and a representative domestic consumer, as we assume in the model, the SDF of the government and that of the domestic consumer coincide. Second, we estimate betas of two-year inflation forecasts with respect to two-year domestic output forecasts. Third, we estimate betas of realized inflation with respect to domestic industrial production. ${ }^{7}$ Finally, we compare these betas to the LC bond beta with respect to the US stock market. Here, we use the US stock market to proxy for the SDF of international investors.

\subsubsection{Cyclicality of LC Bond Returns: Bond-Stock Beta}

Our primary proxy for the hedging value of LC bonds is the beta of LC bond returns with respect to local stock returns. We use the beta of $\mathrm{LC}$ bond returns with respect to the local stock market to capture the hedging benefit of LC debt for domestic consumption, as emphasized by the literature on optimal government debt. Intuitively, a positive LC bond beta indicates that the real expected value of debt repayments declines when the domestic marginal utility of consumption is high, and therefore borrowing with LC debt reduces the domestic consumption volatility. Our benchmark cyclicality measure is based on asset returns, because bond and stock returns are available at higher frequency than macroeconomic data, thereby leading to more precise estimates in a short time series.

We use excess returns of LC bonds and equities over the LC T-bill rate in local currency. We denote the log annualized yield on a nominal LC $n$-quarter bond in country $i$ at quarter $t$ by $y_{i, n, t}^{L C}$. The quarterly log holding period return on the bond is given by:

$$
r_{i, n, t+1}^{L C} \approx \tau_{i, n, t} y_{i, n, t}^{L C}-\left(\tau_{i, n, t}-1 / 4\right) y_{i, n-1, t+1}^{L C},
$$

where $\tau_{i, n, t}$ is the duration of the LC bond in years. ${ }^{8}$ We let $y_{i, 1, t}^{L C}$ denote the log annualized 3 -month local T-bill yield that can be earned by holding the T-bill from time $t$ to time $t+1$.

\footnotetext{
${ }^{7}$ In Appendix A.4.7, we also estimate the betas of realized inflation with respect to GDP for an extended cross-section of 107 countries.

${ }^{8}$ In practice, we approximate $y_{i, n-1, t+1}^{L C}$ by $y_{i, n, t+1}^{L C}$ for the quarterly holding period. We also make the approximation $\tau_{i, n, t} \approx 5$ for the five-year par yield.
} 
Then the log quarterly excess return on LC bonds over the short rate is given by:

$$
x r_{i, n, t+1}^{L C}=r_{i, n, t+1}^{L C}-y_{i, 1, t}^{L C} / 4 .
$$

From the perspective of the local government, the LC bond excess return over the T-bill rate captures the real excess burden of LC bonds over the government's short-term funding rate. Therefore, the cyclicality of these excess returns with respect to local equity excess returns captures the hedging benefit of LC bonds for the domestic borrower. From the perspective of an international lender, these LC excess returns are approximately equal to an excess return measured in US dollars (USD). Movements in the LC/USD exchange rate have the same first-order effect on the long position in the bond and the short position in the T-bill. Therefore, the holding period excess return measured in LC is approximately equal to the excess return measured in USD. ${ }^{9}$ By focusing on the LC bond excess returns over the LC T-bill rate, we are able to largely abstract from currency risk and focus on the duration risk of long-term bonds, which is arguably more closely related to the credibility of domestic monetary policy. This connects our work to the literature on the macroeconomic determinants of bond duration risks in a domestic setting, typically done for the US or a small number of developed countries (for example, Baele et al. (2010); Campbell et al. (2009); David and Veronesi (2013); Duffee (2018); Campbell et al. (2019)).

We define the local equity log excess return as the log quarterly return on local benchmark equity over the $\log$ LC T-bill:

$$
x r_{i, t+1}^{m}=\left(p_{i, t+1}^{m}-p_{i, t}^{m}\right)-y_{i, 1, t}^{L C} / 4,
$$

where $p_{i, t}^{m}$ denotes the $\log$ benchmark equity return index in country $i$ at time $t$. We obtain data on the benchmark equity return index from Bloomberg.

We then compute the local bond-stock beta, $\beta\left(\right.$ bond $_{i}$, stock $\left._{i}\right)$, by regressing LC bond log excess returns on local equity log excess returns:

$$
x r_{i, n, t}^{L C}=a_{i}+\beta\left(\text { bond }_{i}, \text { stock }_{i}\right) \times x r_{i, t}^{m}+\epsilon_{i, t} .
$$

To improve the precision of our beta estimates, we use data that is more finely sampled than the return period, following a long literature starting with Hansen and Hodrick (1980). In particular, we estimate Eqn. (1) using daily observations on overlapping one-quarter holding

\footnotetext{
${ }^{9}$ Since the price of the LC bond may increase or decrease at the end of the holding period, the international lender's dollar returns would be slightly different. We show in Appendix A.4.4 that bond-stock betas are nearly identical if instead we use the exact USD excess returns earned by an international lender with a long position in the bond (or stock) and a short position in the LC T-bill.
} 
period excess returns. We use a tenor of $n=20$ quarters. We use $\beta\left(\right.$ bond $_{i}$, stock $\left._{i}\right)$ as the key measure for the hedging properties of LC bonds for the domestic borrower. The LC bond is a good hedge for the borrower if $\beta\left(\right.$ bond $_{i}$, stock $\left._{i}\right)>0$ and a risky instrument for the borrower if $\beta\left(\right.$ bond $_{i}$, stock $\left._{i}\right)<0$.

\subsubsection{Cyclicality of Inflation Expectations: Inflation-Output Forecast Beta}

To the extent that macroeconomic factors are important in driving LC bond return cyclicality, we would expect an inverse relationship between LC bond-stock betas and the betas of inflation onto output expectations. The intuition is that an increase in inflation expectations should lead to lower LC bond returns, and increased expected economic activity should lead to higher stock returns. We construct a new measure for the pro-cyclicality of inflation expectations. Our choice of variables is dictated by the availability of inflation and business cycle forecasts. Each month, professional forecasters, surveyed by Consensus Economics, forecast inflation and GDP growth for the current and next calendar year. We measure the cyclicality of inflation expectations by regressing the change in the consumer price index (CPI) inflation rate predicted by forecasters on the change in their predicted real GDP growth rate. We pool all revisions for 2006 through 2013 (so that the forecasts were all made post-2005) and run the regression for country $i$ :

$$
\Delta \pi_{i, t}^{\text {Survey }}=a_{i}+\beta\left(\pi_{i}^{\text {Survey }}, g d p_{i}^{\text {Survey }}\right) \times \Delta g d p_{i, t}^{\text {Survey }}+\epsilon_{i, t},
$$

where $t$ indicates the date of the forecast revision. The revisions to inflation forecasts $\left(\Delta \pi_{i, t}^{\text {Survey }}\right)$ and GDP growth forecasts $\left(\Delta g d p_{i, t}^{\text {Survey }}\right)$ are percentage changes of mean forecasts made three months before. The coefficient $\beta\left(\pi_{i}^{\text {Survey }}, g d p_{i}^{\text {Survey }}\right)$ measures the cyclicality of inflation expectations and is the coefficient of interest.

Because forecasts are made for calendar years, the forecast horizon can potentially vary. Consensus Economics has forecasts for the annual inflation rate up to two years in advance. This means that in January 2008, the forecast of calendar year 2008 inflation is effectively 11 months ahead and the forecast of calendar year 2009 is 23 months ahead. We focus on revisions to the two-year forecast (13-23 months ahead) to minimize variation in the forecast horizon.

\subsubsection{Cyclicality of Realized Inflation: Realized Inflation-Output Beta}

While asset prices are forward-looking, and hence are most naturally linked to inflation and output forecasts, it is useful to verify that the composition of debt portfolios also lines up with the cyclicality of realized inflation and output. We compute the realized inflation- 
output beta by regressing the change in the inflation rate on the change in the industrial production growth rate: ${ }^{10}$

$$
\Delta \pi_{i, t}=a_{i}+\beta\left(\pi_{i}, I P_{i}\right) \Delta I P_{i, t}+\epsilon_{t}
$$

where $\Delta \pi_{i, t}$ is the 12-month change in the year-over-year inflation rate, and $\Delta I P_{i, t}$ is the 12 -month change in the year-over-year industrial production growth rate. We estimate Eqn. (3) using monthly overlapping data of 12 -month changes. The coefficient $\beta\left(\pi_{i}, I P_{i}\right)$ measures the realized inflation cyclicality with respect to output. We obtain the seasonally adjusted CPI and the industrial production index from Haver Analytics between 2005 and 2014.

\subsection{Local Currency Debt Shares}

In this section, we discuss how we measure the LC debt share. We measure the LC debt share in several different ways and show that our empirical findings are robust whether we use the LC share in debt held by all investors or the LC share in debt held by external (i.e. non-domestic) investors. The advantage of considering the LC debt share of total debt is that in practice governments have direct control over the LC debt share in total debt outstanding, suggesting that it might be a good measure of optimal debt policy. Moreover, empirical proxies for the LC debt share in all debt are more precise than those for the LC debt share held by external investors. On the other hand, it is important to consider the external LC debt share, because inflating away LC debt is only an aggregate transfer of resources to the domestic economy when the debt is owned by international lenders. Under the assumptions of lump-sum taxes and a representative domestic consumer, government debt held by domestic lenders does not affect the optimal inflation policy. ${ }^{11}$

\subsubsection{LC Share in Total Government Debt}

For developed countries, we construct the share of LC debt based on the OECD Central Government Debt Statistics and supplement this data with hand-collected statistics from individual central banks. ${ }^{12}$

For emerging markets, we measure the share of LC debt in total government debt using

\footnotetext{
${ }^{10}$ We use industrial production because it is available monthly, whereas GDP and consumption are only available quarterly for most of our countries. Using overlapping observations increases the precision of our estimates. In Appendix A.4.7, we also estimate the realized inflation-output beta using GDP for a large number of countries.

${ }^{11}$ We formalize this argument in Appendix B.2.

${ }^{12}$ The OECD Central Bank Debt Statistics database was discontinued in 2010. We collected the statistics between 2010 and 2014 from individual central banks.
} 
the Debt Securities Statistics from the Bank for International Settlements (BIS), supplemented with statistics from individual central banks. Table 16C of the BIS Debt Securities Statistics reports the instrument composition for outstanding domestic bonds and notes issued by the central government $\left(D_{t}^{d o m}\right)$ starting in 1995. Table 12E of the BIS Debt Securities Statistics reports total international debt securities outstanding issued by the general government $\left(D_{t}^{i n t}\right)$. For emerging markets, $D_{t}^{i n t}$ offers a good proxy for central government FC debt outstanding because the vast majority of sovereign debt issued in international markets is denominated in foreign currency, and local governments rarely tap international debt markets. The share of LC debt is computed as the ratio of the fixed-coupon domestic sovereign debt outstanding $\left(D_{t}^{\text {dom, fix }}\right)$ over the sum of domestic and international government debt:

$$
s_{t}=\frac{D_{t}^{d o m, f i x}}{D_{t}^{d o m}+D_{t}^{i n t}} .
$$

Inflation-linked debt, floating-coupon debt, and FC debt are all treated as real liabilities.

\subsubsection{LC Share in External Government Debt}

We estimate the share of LC in government debt held by international investors from three independent and complementary data sources. First, we calculate the share of LC debt in government debt owned by US domiciled investors. US investors report their security-level holdings as part of the Treasury International Capital (TIC) data. We calculate the LC debt share by dividing the total value of government debt in the borrowing country's currency by the total amount of that country's sovereign debt owned by US investors. The advantage of this data, and the reason we use it as our benchmark external debt share, is that it is available over the full sample over which we measure the bond-stock beta. The primary drawback is that it is limited to US investors.

The second proxy of the LC debt share in externally held debt is the share among global mutual funds based on Morningstar data from Maggiori et al. (2019). The advantage of this data is that it includes not only US mutual funds, but also those from the euro area, Great Britain, Canada, and several other developed countries. The Morningstar data complements the US TIC data by demonstrating that our results hold for global investors. Its drawback is that mutual funds are only one part of global portfolio flows. However, Maggiori et al. (2019) demonstrate that mutual fund investors are largely representative of aggregate portfolio investment.

Third, we make use of the enhanced BIS locational banking statistics (LBS) available to

central banks. Starting in 2013Q4, the enhanced BIS LBS reports holdings of government 
securities of BIS reporting banks by currency. ${ }^{13}$ In terms of the currency breakdown, the BIS LBS reports debt outstanding denominated in US dollars, euros, British pounds, Japanese yen, Swiss francs, and all other currencies as an aggregate. We treat the "all other currencies" field as the local currency of the sample country, except for countries where the local currency is a direct reporting currency (i.e., the United States, Germany, the United Kingdom, Japan, and Switzerland). We average the BIS LC debt share over 2014Q1 to 2017Q2.

\subsection{Summary Statistics}

Figure 1 plots our LC bond-local stock beta, $\beta\left(\right.$ bond $_{i}$, stock $\left._{i}\right)$, estimated from Eqn. (1) by country. The 95 percent confidence intervals are based on Hansen-Hodrick standard errors with 120-day lags. ${ }^{14}$ The betas are precisely estimated and most of them are statistically significantly different from zero. Developed markets (shown in green) generally have negative bond-stock betas, and emerging markets (shown in red) have higher bond-stock betas, with many countries having positive bond-stock betas. Even within emerging markets, we document economically and statistically significant cross-country heterogeneity in LC bond-stock betas.

Table 1 reports summary statistics across countries. Emerging market realized inflation is 2.2 percentage points higher than in developed markets (Column 1), and survey-based expected inflation is 1.8 percentage points higher in emerging markets than in developed markets (Column 2). For LC bonds, five-year LC yields are 3.4 percentage points higher in emerging markets than in developed markets (Column 3). The hedging properties of LC bonds are significantly different between emerging and developed markets. LC bond returns are more pro-cyclical in emerging markets than in developed countries (Column 4), and expected inflation and realized inflation are more counter-cyclical in emerging markets than in developed countries (Columns 5 and 6).

Table 2 reports summary statistics for our four LC debt share measures, i.e. the LC share in total debt, and the LC share in external debt based on US TIC Data, global mutual fund holdings from Maggiori et al. (2019), and the BIS LBS. We see that developed market governments borrow almost completely in LC, but emerging markets' LC debt shares are only $61 \%$ of total debt and $55 \%$ of external debt according to TIC data. Unsurprisingly, total debt is always weighted more towards LC debt than external debt. Some differences across the three external debt measures are due to the fact that the data are available over

\footnotetext{
${ }^{13}$ Prior to the data enhancement, the earlier BIS LBS did not contain a sectoral breakdown between governments and non-financial corporates. We note that the coverage of the BIS LBS data on cross-border holdings of government debt securities is incomplete among BIS reporting countries. Our estimates are only based on the reporting countries that provide data on banks' holdings of government debt securities.

${ }^{14}$ The regression table for individual bond-stock betas is reported in Appendix A.3.
} 
different time periods. In Appendix Figure A.1, we show that LC currency debt shares based on TIC and Maggiori et al. (2019) are nearly identical in 2015.

\section{Figure 1: Individual Country Bond Betas}

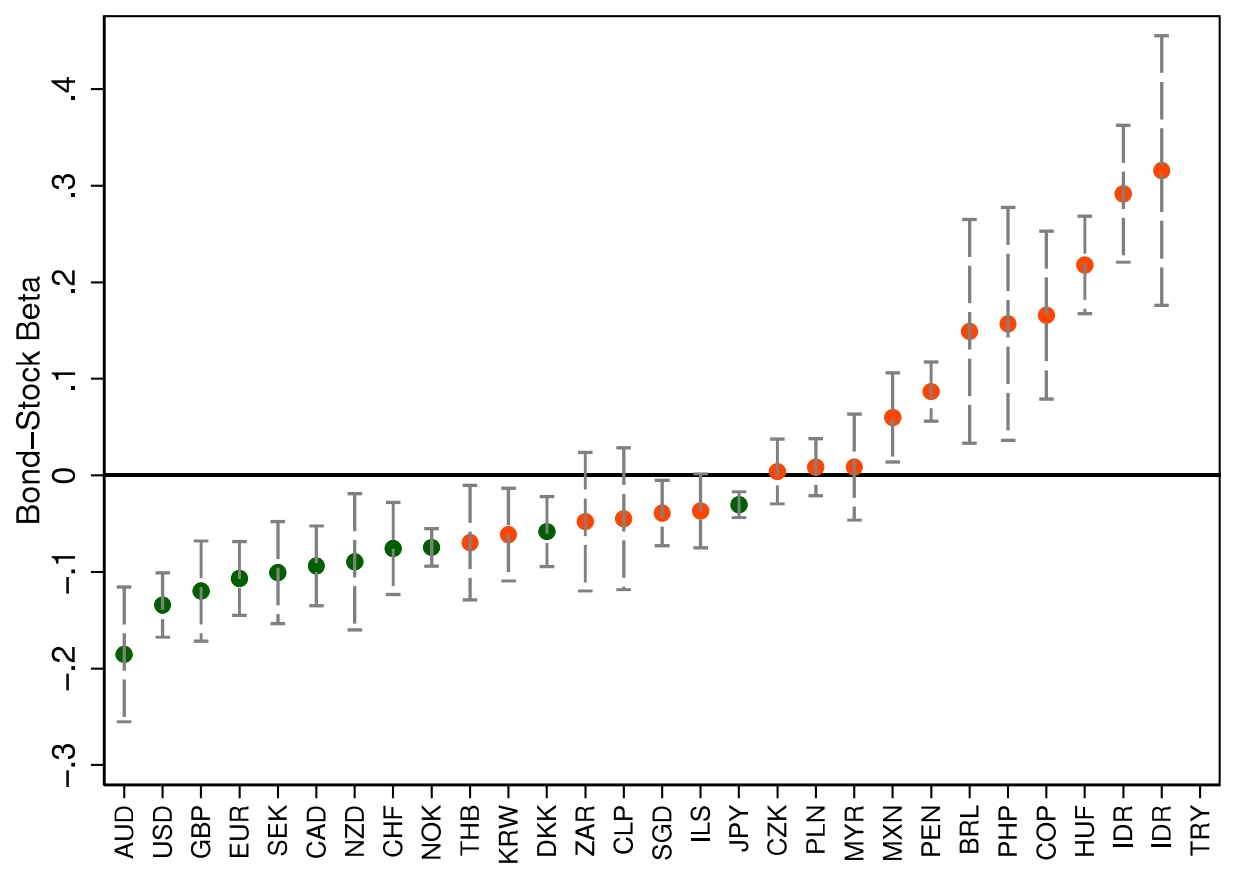

Note: This figure plots the beta of LC bond log excess returns onto local log equity excess returns estimated as in Eqn. (1) for each country. The green dots denote point estimates for developed markets. The red dots denote point estimates for emerging markets. The vertical bars denote $95 \%$ confidence interval based on Hansen-Hodrick standard errors with 120-day lags. 


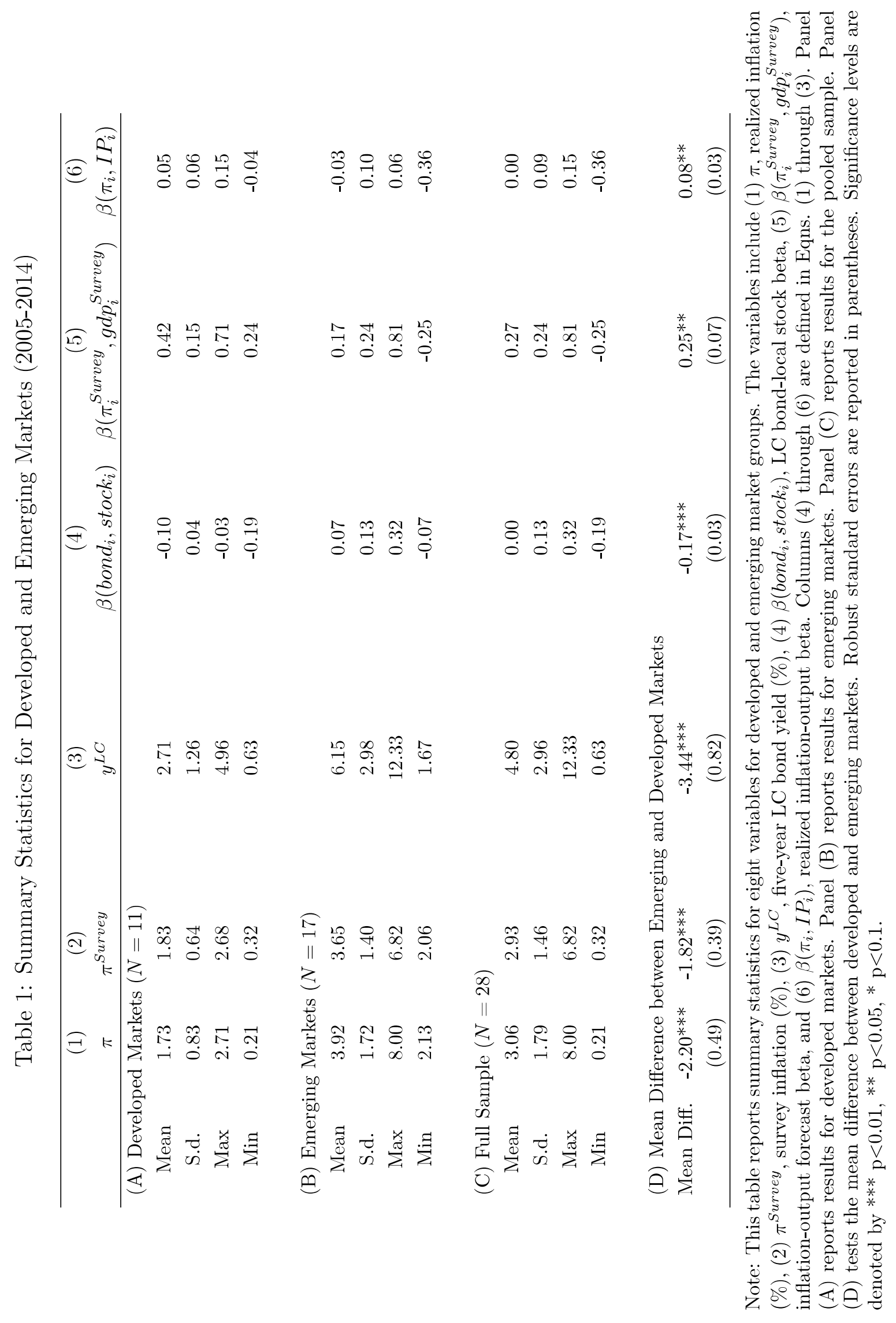


Table 2: Summary Statistics for LC Debt Shares in Total and External Government Debt

\begin{tabular}{|c|c|c|c|c|}
\hline Measure & $\begin{array}{c}(1) \\
s^{T O T}\end{array}$ & $\begin{array}{l}(2) \\
s^{T I C}\end{array}$ & $\begin{array}{c}(3) \\
s^{M N S}\end{array}$ & $\begin{array}{l}(4) \\
S^{B I S}\end{array}$ \\
\hline Years & $2005-2014$ & $2007-2014$ & 2015 & $2014-2017$ \\
\hline \multicolumn{5}{|c|}{ (A) Developed Markets } \\
\hline Mean & 89.16 & 89.73 & 87.85 & 69.58 \\
\hline S.d. & 11.33 & 14.04 & 12.59 & 35.48 \\
\hline Max & 100.00 & 100.00 & 99.75 & 99.89 \\
\hline Min & 65.91 & 55.92 & 65.79 & 8.79 \\
\hline \multicolumn{5}{|c|}{ (B) Emerging Markets } \\
\hline Mean & 61.17 & 54.56 & 63.96 & 45.42 \\
\hline S.d. & 25.52 & 28.81 & 26.83 & 30.34 \\
\hline Max & 100.00 & 100.00 & 99.40 & 99.85 \\
\hline Min & 11.97 & 7.57 & 20.32 & 8.26 \\
\hline \multicolumn{5}{|c|}{ (C) Full Sample } \\
\hline Mean & 72.16 & 68.37 & 73.35 & 54.91 \\
\hline S.d. & 25.04 & 29.51 & 25.03 & 34.00 \\
\hline Max & 100.00 & 100.00 & 99.75 & 99.89 \\
\hline Min & 11.97 & 7.57 & 20.32 & 8.26 \\
\hline \multicolumn{5}{|c|}{ (D) Mean Difference between Emerging and Developed Market } \\
\hline Mean Diff. & $\begin{array}{c}28.00^{* * *} \\
(7.09)\end{array}$ & $\begin{array}{c}35.17^{* * *} \\
(8.19)\end{array}$ & $\begin{array}{c}23.89^{* * *} \\
(7.55)\end{array}$ & $\begin{array}{l}24.16^{*} \\
(12.92)\end{array}$ \\
\hline
\end{tabular}

Note: This table reports summary statistics for four variables for developed and emerging market groups. The variables include (1) $s^{T O T}$, percentage share of LC debt in total sovereign debt portfolios for the period 2005-2014, (2) $s^{T I C}$, percentage share of LC debt in US holdings of sovereign debt, 2007-2014, (3) $s^{M N S}$, percentage share of LC debt in foreign mutual fund holdings of sovereign debt in 2015 from Maggiori et al. (2019), (4) $s^{B I S}$, percentage share of LC debt in holdings of government securities of BIS reporting banks from the enhanced BIS locational banking statistics (LBS) for the period 2014Q1-2017Q2. Panel (A) reports results for developed markets. Panel (B) reports results for emerging markets. Panel (C) reports results for the pooled sample. Panel (D) tests the mean difference between developed and emerging markets. Robust standard errors are reported in parentheses. Significance levels are denoted by ${ }^{* * *} \mathrm{p}<0.01,{ }^{* *} \mathrm{p}<0.05,{ }^{*}$ $\mathrm{p}<0.1$.

\subsection{LC Debt Shares and Bond Risks}

Figure 2 summarizes our key empirical finding. Panel (A) shows a clearly downward-sloping relationship between LC bond-stock betas and the LC debt share of total government debt. Panel (B) shows a similar relationship with the LC debt share in externally-held debt from TIC. This result is puzzling from the perspective of standard optimal government debt theory, because a positive LC bond-stock beta indicates that LC debt helps the borrower 
hedge the volatility of domestic consumption.

Table 3 examines this relationship more formally and presents cross-sectional regressions of the total LC debt share on measures of LC bond and inflation cyclicality. The first column shows that a 0.17 increase in the bond-stock beta, corresponding to the average difference between emerging and developed markets, is associated with a 18 percentage point reduction in the LC debt share and this relation is statistically significant at the $1 \%$ level. Columns (2) and (3) show that LC debt shares decrease with expected and realized inflation-output betas, as one would expect if LC bonds fall with inflation and stocks rise with output. Column (4) shows that the baseline relation is robust to controlling for mean log GDP per capita, the exchange rate regime, and the share of commodities in total exports. ${ }^{15} \mathrm{We}$ also control for the beta of the local stock market on the US stock market in order to ensure that the results are not driven by differences in whether a country's equity market is risky for international lenders. These consistent results across asset price based and macroeconomic cyclicality measures provide important motivation for our model, suggesting that macroeconomic factors are key drivers of LC bond risks and returns across countries.

\footnotetext{
${ }^{15}$ We use the exchange rate regime developed by Reinhart and Rogoff (2004) and the commodity share is defined as the sum of "Ores and Metals" and "Fuel" exports as a percentage of total merchandise exports from World Bank World Development Indicators.
} 
Figure 2: Local Currency Debt Shares and Bond Betas

(A) Total Government Debt

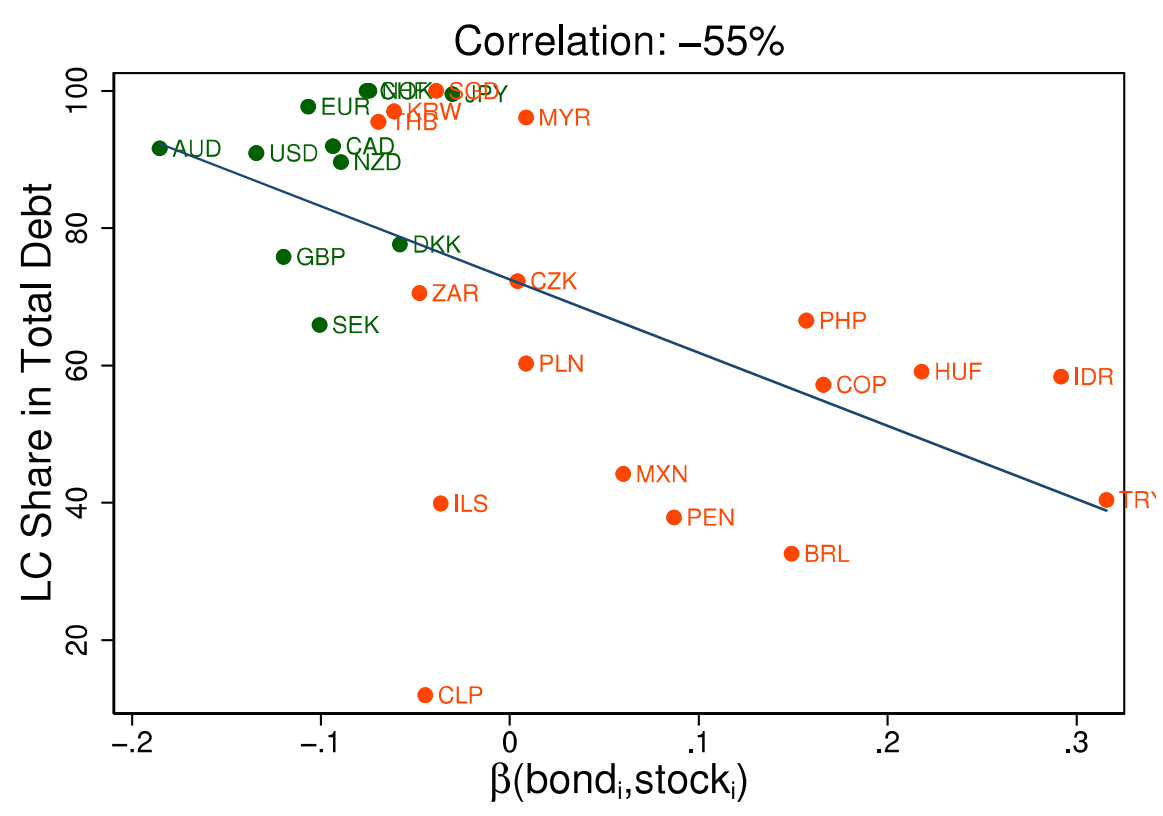

(B) External Government Debt

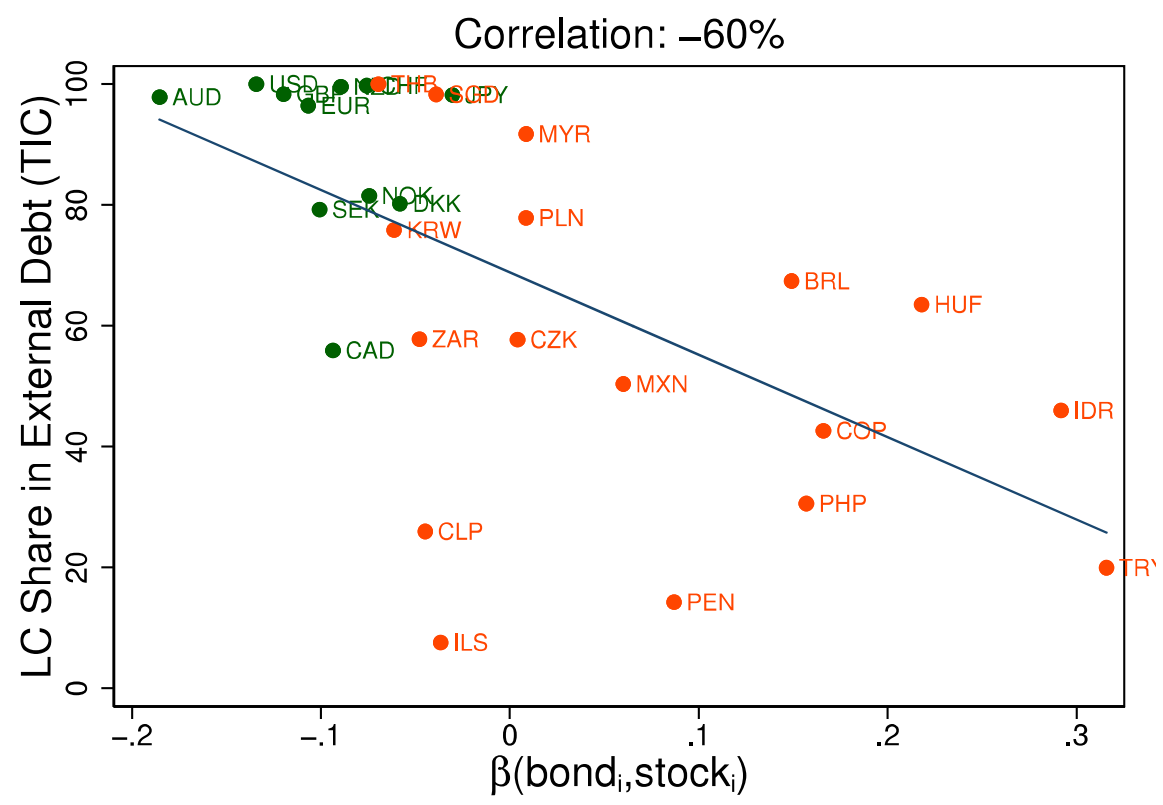

Note: Panel (A) shows the share of LC debt as a fraction of total central government debt (in \%) over the period 2005-2014 vs. the LC bond-local stock beta. Panel (B) shows the share of LC debt in US investors' holdings of government debt from the TIC data over the period 2007-2014 vs. the LC bond-stock beta. For each country, the LC bond-stock beta is estimated as the slope coefficient of quarterly LC bond log excess returns onto local stock market log excess returns over the same time period:

$$
x r_{i, n, t}^{L C}=a_{i}+\beta\left(\text { bond }_{i}, \text { stock }_{i}\right) \times x r_{i, t}^{m}+\epsilon_{i, t} .
$$

Emerging markets are shown in red and developed markets in green. Three-letter codes indicate currencies. For a list of currency codes, see Appendix A.1. 
Table 3: LC Debt Shares in Total Government Debt onto LC Bond Cyclicality

\begin{tabular}{|c|c|c|c|c|}
\hline Local Currency Debt Share & $\begin{array}{c}(1) \\
s^{T O T}\end{array}$ & $\begin{array}{c}(2) \\
s^{T O T}\end{array}$ & $\begin{array}{c}(3) \\
s^{T O T}\end{array}$ & $\begin{array}{c}(4) \\
s^{T O T}\end{array}$ \\
\hline$\beta\left(\right.$ bond $_{i}$, stock $\left._{i}\right)$ & $\begin{array}{c}-106.64^{* * *} \\
(20.37)\end{array}$ & & & $\begin{array}{c}-93.25^{* *} \\
(35.63)\end{array}$ \\
\hline$\beta\left(\pi_{i}^{\text {Survey }}, g d p_{i}^{\text {Survey }}\right)$ & & $\begin{array}{c}58.61^{* * *} \\
(13.95)\end{array}$ & & \\
\hline$\beta\left(\pi_{i}, I P_{i}\right)$ & & & $\begin{array}{c}68.84^{* *} \\
(34.91)\end{array}$ & \\
\hline$\beta\left(\right.$ stock $_{i}$, stock $\left._{U S}\right)$ & & & & $\begin{array}{c}11.21 \\
(24.48)\end{array}$ \\
\hline $\log (\mathrm{GDP})$ & & & & $\begin{array}{c}2.99 \\
(4.53)\end{array}$ \\
\hline FX Regime & & & & $\begin{array}{c}0.43 \\
(3.87)\end{array}$ \\
\hline Commodity Share & & & & $\begin{array}{l}-0.23 \\
(0.25)\end{array}$ \\
\hline Constant & $\begin{array}{c}72.54^{* * *} \\
(4.29)\end{array}$ & $\begin{array}{c}56.42^{* * *} \\
(5.89)\end{array}$ & $\begin{array}{c}71.93^{* * *} \\
(4.65)\end{array}$ & $\begin{array}{c}36.93 \\
(51.51)\end{array}$ \\
\hline Observations & 28 & 28 & 28 & 28 \\
\hline R-squared & 0.30 & 0.32 & 0.06 & 0.38 \\
\hline
\end{tabular}

Note: This table shows cross-country regressions of the LC debt share in total central government debt, $s^{T O T}$ (between 0 and 1), on measures of bond return and inflation cyclicality. The independent variables in the first three columns are the bond-stock beta $\beta\left(\right.$ bond $_{i}$, stock $\left._{i}\right)$, the inflation forecast beta $\beta\left(\pi_{i}^{\text {Survey }}, g d p_{i}^{\text {Survey }}\right)$, and the realized inflation-output beta $\beta\left(\pi_{i}, I P_{i}\right)$, as described in Table 1. In column (4), we control for the local stock-US stock beta $\beta\left(\right.$ stock $_{i}$, stock $\left._{U S}\right)$, average log per capita GDP between 2005 and 2014, the average exchange rate classification from Reinhart and Rogoff (2004), and the commodity share of exports. The local stock-US stock beta,$\beta\left(s t o c k_{i}\right.$, stock $\left._{U S}\right)$, is estimated as the regression coefficient of local log excess stock returns onto US log excess stock returns. The commodity share of exports is defined as the sum of "Ores and Metals" and "Fuel" exports as a percentage of total merchandise exports from World Bank World Development Indicators. More details on variable definitions can be found in Section 2. Standard errors are based on Huber-White robust standard errors and bootstrap standard errors from a wild bootstrap (Davison and Hinkley (1997)), whichever one is larger. Appendix A.6 provides further details of the bootstrap procedures and how they account for correlated estimation error in the betas. Significance levels indicated by ${ }^{* * *} \mathrm{p}<0.01,{ }^{* *} \mathrm{p}<0.05,{ }^{*} \mathrm{p}<0.1$.

In Table 4, we perform the same exercise for our three measures of the currency composition of external sovereign debt. We find that the slope coefficient for the bond-stock beta is quantitatively unchanged compared to Table 3 and highly statistically significant. These results provide a bridge to the theoretical framework, where we focus on the government borrowing from international lenders. 
Table 4: LC Debt Shares in External Debt onto LC Bond Cyclicality

\begin{tabular}{|c|c|c|c|c|c|c|}
\hline Local Currency Debt Share & $\begin{array}{c}(1) \\
s^{T I C}\end{array}$ & $\begin{array}{c}(2) \\
s^{M N S}\end{array}$ & $\begin{array}{c}(3) \\
s^{B I S}\end{array}$ & $\begin{array}{c}(4) \\
s^{T I C}\end{array}$ & $\begin{array}{c}(5) \\
s^{M N S}\end{array}$ & $\begin{array}{c}(6) \\
s^{B I S}\end{array}$ \\
\hline$\beta\left(\right.$ bond $_{i}$, stock $\left._{i}\right)$ & $\begin{array}{c}-136.36^{* * *} \\
(25.37)\end{array}$ & $\begin{array}{c}-104.94^{* * *} \\
(22.16)\end{array}$ & $\begin{array}{c}-126.00^{* * *} \\
(30.00)\end{array}$ & $\begin{array}{c}-107.84^{* *} \\
(51.28)\end{array}$ & $\begin{array}{c}-99.44^{* *} \\
(35.52)\end{array}$ & $\begin{array}{c}-151.00^{* *} \\
(54.41)\end{array}$ \\
\hline$\beta\left(\right.$ stock $_{i}$, stock $\left._{U S}\right)$ & & & & $\begin{array}{c}1.11 \\
(22.20)\end{array}$ & $\begin{array}{c}5.89 \\
(23.24)\end{array}$ & $\begin{array}{c}-2.75 \\
(29.89)\end{array}$ \\
\hline $\log (\mathrm{GDP})$ & & & & $\begin{array}{c}4.61 \\
(5.86)\end{array}$ & $\begin{array}{c}1.18 \\
(4.76)\end{array}$ & $\begin{array}{l}-4.26 \\
(7.41)\end{array}$ \\
\hline FX Regime & & & & $\begin{array}{c}2.04 \\
(4.07)\end{array}$ & $\begin{array}{c}5.17 \\
(4.20)\end{array}$ & $\begin{array}{l}-0.36 \\
(7.69)\end{array}$ \\
\hline Commodity Share & & & & $\begin{array}{l}-0.33 \\
(0.24)\end{array}$ & $\begin{array}{l}-0.23 \\
(0.23)\end{array}$ & $\begin{array}{l}-0.35 \\
(0.26)\end{array}$ \\
\hline Constant & $\begin{array}{c}68.85^{* * *} \\
(4.84)\end{array}$ & $\begin{array}{c}73.72^{* * *} \\
(4.25)\end{array}$ & $\begin{array}{c}55.35^{* * *} \\
(6.05)\end{array}$ & $\begin{array}{c}25.01 \\
(56.07)\end{array}$ & $\begin{array}{c}46.83 \\
(51.59)\end{array}$ & $\begin{array}{l}107.85 \\
(66.09)\end{array}$ \\
\hline Observations & 28 & 28 & 28 & 28 & 28 & 28 \\
\hline R-squared & 0.36 & 0.30 & 0.23 & 0.45 & 0.36 & 0.28 \\
\hline
\end{tabular}

Note: This table shows cross-country regressions of the LC debt share, $s$ (between 0 and 1), based on external debt (debt held by non-residents) on bond return cyclicality. In columns (1) and (4), the dependent variable $s^{T I C}$ denotes the share of LC debt in US investors' portfolio holdings of government debt from TIC data. In columns (2) and (5), the dependent variable $s^{M N S}$ denotes the LC debt share in cross-border mutual fund portfolio holdings of government debt from Morningstar. In columns (3) and (6), the dependent variable $s^{B I S}$ denotes the LC debt share in government debt reported by BIS reporting banks from the BIS Locational Banking Statistics. The independent variable in the first three columns is the LC bond-stock beta $\beta\left(\right.$ bond $_{i}$, stock $\left._{i}\right)$, as described in Table 1. In column (4) through (6), we control for the local stock-US stock beta $\beta\left(\right.$ stock $_{i}$, stock $\left._{U S}\right)$, average log per capita GDP between 2005 and 2014, the average exchange rate classification from Reinhart and Rogoff (2004), and the commodity share of exports. The local stock-US stock beta $\beta\left(\right.$ stock $_{i}$, stock $\left._{U S}\right)$, is estimated as the regression coefficient of local log excess stock returns onto US log excess stock returns. The commodity share of exports is defined as the sum of "Ores and Metals" and "Fuel" exports as a percentage of total merchandise exports from World Bank World Development Indicators. More details on variable definitions can be found in Section 2. Standard errors are based on Huber-White robust standard errors and bootstrap standard errors from a wild bootstrap (Davison and Hinkley (1997)), whichever one is more conservative. Appendix A.6 provides further details of the bootstrap procedure and how it accounts for potentially correlated estimation error in the betas. Significance levels indicated by $* * *$ $\mathrm{p}<0.01,{ }^{* *} \mathrm{p}<0.05,{ }^{*} \mathrm{p}<0.1$.

We provide additional robustness checks for our main empirical result in Appendix A.4. We show that our result is robust to using long-term debt, excluding the financial crisis, adjusting for default risk, adjusting for the FX hedging error, and weighting by per capita GDP. The robust result for the LC debt share in long-term debt is important, as Missale and Blanchard (1994) argue that shorter debt maturity reduces the incentive to inflate away debt. We also show the relationship between LC debt and LC bond-stock betas holds for the LC Debt/GDP ratio, rather than the LC debt share. Furthermore, we show that the 
relationship between the LC debt and LC bond-stock betas holds for all sample years when the betas are estimated using rolling windows over time. The ranking of the bond-stock betas across countries is very persistent over our sample period. Finally, we note that we do not interpret the relationship between the LC debt share and the hedging property of the LC debt as causal. Instead, we document a robust bivariate relationship between two variables that are central to the study of sovereign debt. In our theoretical model, monetary policy credibility drives endogenous variation in both variables.

\subsection{Bond Risk Premia and Monetary Policy Credibility}

In this section, we show that the bond-stock beta is highly correlated with the LC bond risk premium and a de facto measure of monetary policy commitment. These additional empirical results motivate us to develop a model that features risk-averse lenders and varying degrees of monetary policy commitment.

We first establish that the LC bonds with the best hedging value for the domestic government are risky for international lenders. To see this, we estimate the beta of LC bond returns with respect to US stock returns from a regression:

$$
x r_{i, n, t}^{L C}=a_{i}+\beta\left(\text { bond }_{i}, \text { stock }_{U S}\right) \times x r_{U S, t}^{m}+\epsilon_{i, t} \text {. }
$$

The correlation between the LC bond-US stock beta, $\beta\left(\right.$ bond $_{i}$, stock $\left._{U S}\right)$, and the LC bondlocal stock beta, $\beta\left(\right.$ bond $_{i}$, stock $\left._{i}\right)$, is $89 \%{ }^{16}$

Second, we establish the relationship between bond-stock betas and the LC bond risk premium, defined as the log expected real return on a LC bond in excess of a global real risk-free rate. We proxy for the risk premium on the LC bond in country $i$ as follows:

$$
\overline{R P}_{i, n}=\bar{y}_{i, n}^{L C}-\bar{\pi}_{i}^{\text {Survey }}-\left(\bar{y}_{U S, 1}-\bar{\pi}_{U S}^{\text {Survey }}\right)
$$

where a bar indicates the mean from 2005 to 2014. This formulation is effectively imputing the risk premium as the difference between currency-specific real interest rates. ${ }^{17}$

Panel (A) of Figure 3 shows that the bond-US stock beta, $\beta\left(\right.$ bond $_{i}$, stock $\left._{U S}\right)$, is $57 \%$ correlated with the LC bond risk premium. Therefore, international lenders require a higher risk premium for holding LC bonds if LC bond returns are more pro-cyclical. In Appendix

\footnotetext{
${ }^{16}$ More details on the risk of LC bonds from the international lender's perspective can be found in Appendix A.5.

${ }^{17}$ Due to our short sample, ex post bond risk premia, measured as realized excess returns, are extremely noisy. We therefore prefer ex ante measures, corresponding to those that governments see when making issuance decisions.
} 
A.7.2, we formally estimate the relationship between the risk premium and the bond-US stock beta using the generalized method of moments to account for generated regressors. We obtain a statistically significant coefficient of 8.96, i.e. an asset with a unit beta with respect to the US stock market has a risk premium of $8.96 \%$. This number is very close to and not statistically significantly different from the US equity premium of $8.1 \%$ reported by Campbell (2003).

So far, we have documented that LC debt with better hedging benefits to domestic consumers tend to be riskier for international lenders, who in turn require to be paid higher risk premia for holding this debt. One might wonder what country fundamentals drive these correlations. We provide evidence for a link between the bond-stock beta and a de facto measure of monetary policy credibility. Using Financial Times articles over the period 1995-2015, we construct the correlation between the keywords "debt" and "inflation" for each country as a proxy for inverse monetary policy credibility. ${ }^{18}$ Panel (B) of Figure 3 shows that this de facto monetary policy credibility measure is strongly correlated with the bond-stock beta, with the correlation equal to $71 \%$.

\footnotetext{
${ }^{18}$ The intuition is that if inflation is solely determined by the central bank and debt is determined by the fiscal authority, these topics should be discussed separately, and the correlation should be low. On the other hand, if inflation and debt are determined by the same central government, we would expect newspaper articles to discuss both jointly, and the correlation should be high. We count the number of articles containing both keywords and the country name and divide them by the geometric average of the articles that contain one of the keywords combined with the country name. We prefer a de facto measure of central bank credibility because recent measures of de jure central bank independence have been found to be uncorrelated with average inflation (Crowe and Meade, 2007).
} 
Figure 3: LC Bond Betas, Bond Risk Premia and Monetary Policy Credibility

(A) Bond-Stock Beta vs. LC Bond Risk Premium

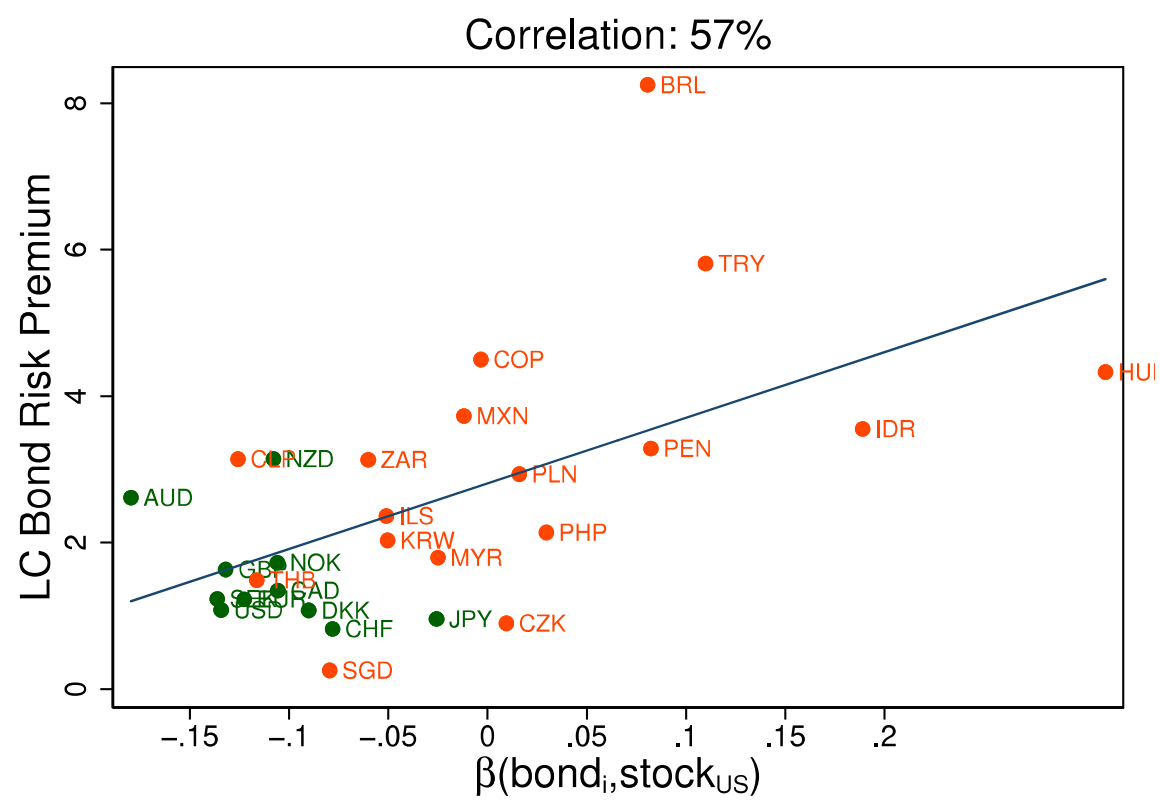

(B) Bond-Stock Beta vs. De Facto Monetary Policy Credibility

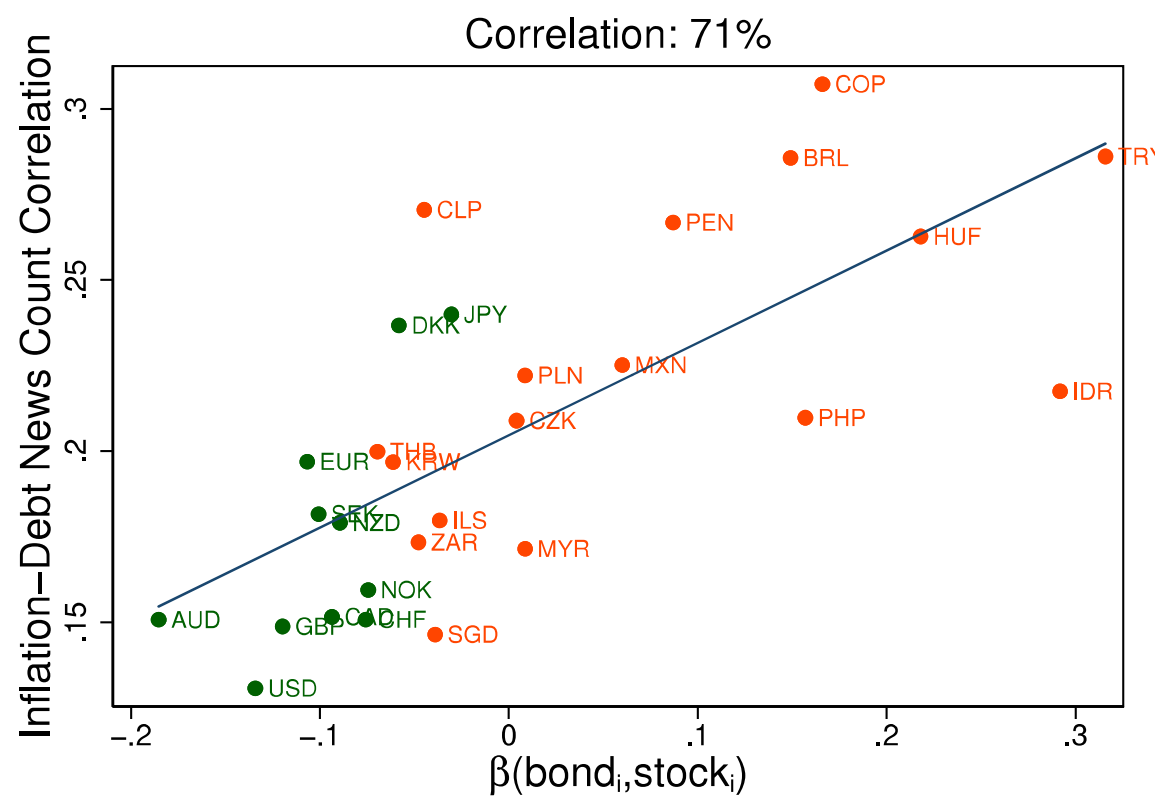

Note: Panel (A) plots the average risk premium on LC bonds against the LC bond-US stock beta. LC bond risk premia are estimated according to Eqn. (5). Panel (B) plots the correlation of the keywords "debt" and "inflation" in Financial Times articles from 1996-2015 from ProQuest Historical Newspapers against the LC bond-local stock beta. 


\section{Model}

This section describes a two-period model of a small open economy borrowing from international lenders. The domestic government's problem is to maximize the welfare of the representative domestic consumer by choosing the currency composition of its debt and state-contingent inflation. We solve this problem for two types of governments: those that can commit to a state-contingent inflation policy function and those that cannot. The model generates endogenous differences in inflation cyclicality and the LC debt share from exogenous differences in governments' ability to commit to an inflation policy. Because LC bond returns are linked to inflation and stock returns to output surprises, the model can explain the empirical relationship between LC bond return cyclicality and LC debt shares that we documented in Section 2. Throughout, we use a superscript asterisk to denote quantities for international lenders and lower-case variables to denote logs.

\subsection{Environment}

\subsubsection{Domestic Government}

A benevolent government maximizes the welfare of the representative domestic agent, where the agent has utility with constant relative risk aversion (CRRA) over real domestic consumption $C_{2}$ and faces a quadratic loss from inflation:

$$
\mathbb{E} U\left(C_{2}, \pi_{2}\right)=\mathbb{E}\left[\frac{C_{2}^{1-\gamma}}{1-\gamma}-\frac{\alpha}{2} \pi_{2}^{2}\right] .
$$

The government needs to raise an exogenous and fixed amount of real revenue, $\frac{\bar{D}}{R^{*}}$, and can do so either borrowing in LC or FC

$$
Q^{L C} D^{L C}+Q^{F C} D^{F C}=\frac{\bar{D}}{R^{*}}
$$

Here, $Q^{L C}$ and $Q^{F C}$ denote period 1 bond prices and $D^{L C}$ and $D^{F C}$ debt face values, all measured in real domestic consumption units. $D^{L C}$ and $D^{F C}$ are required to be non-negative. $R^{*}$ denotes the exogenous real global interest rate. Equivalently, the government chooses the LC debt share, $s \in[0,1]$, defined as

$$
s=\frac{Q^{L C} D^{L C}}{\bar{D} / R^{*}} .
$$

LC and FC face values are then given by $D^{L C}=s \times \frac{\bar{D}}{R^{*}} \times \frac{1}{Q^{L C}}$ and $D^{F C}=(1-s) \times \frac{\bar{D}}{R^{*}} \times \frac{1}{Q^{F C}}$. We assume that the domestic government has access to lump-sum taxation. Domestic 
real consumption in the second period is endogenous and equals the endowment $X_{2}$, net of real debt repayments $D_{2}\left(X_{2}\right)$ :

$$
C_{2}=X_{2}-D_{2}\left(X_{2}\right)
$$

Real debt repayments $D_{2}\left(X_{2}\right)$ equal the real value of LC debt repayments plus FC debt repayments:

$$
D_{2}=s \times \frac{\bar{D}}{R^{*}} \times R_{2}^{L C}+(1-s) \times \frac{\bar{D}}{R^{*}} \times R_{2}^{F C},
$$

where $R_{2}^{L C}$ and $R_{2}^{F C}$ denote gross returns measured in real domestic consumption units on $\mathrm{LC}$ and FC bonds. The real amount of domestic consumption units required to repay the LC debt equals the real revenue raised through LC debt, $s \times \frac{\bar{D}}{R^{*}}$, times the return on that debt in real domestic consumption units. The real amount of domestic consumption units required to repay $\mathrm{FC}$ debt similarly equals the real revenue raised through $\mathrm{FC}$ debt, $(1-s) \times \frac{\bar{D}}{R^{*}}$, times the corresponding return in real domestic consumption units.

The domestic representative agent consumes a domestic consumption good, which differs from the global consumption good consumed by international lenders. We define the real exchange rate $\mathcal{E}_{t}$ as the number of real domestic consumption goods obtainable in exchange for one unit of the real global consumption good at time $t$. We normalize the period 1 real exchange rate to one, $\mathcal{E}_{1} \equiv 1$. A higher $\mathcal{E}_{t}$ denotes a real appreciation of the local currency. The returns $R_{2}^{L C}$ and $R_{2}^{F C}$ are measured in real domestic consumption units to match the units in Eqn. (10), so we have:

$$
\begin{aligned}
R_{2}^{L C} & =\frac{\exp \left(-\pi_{2}\left(X_{2}\right)\right)}{Q^{L C}} \\
R_{2}^{F C} & =\frac{R^{*}}{\mathcal{E}_{2}}
\end{aligned}
$$

Eqn. (11) shows that the domestic government's real cost of repaying LC debt falls with inflation. It also shows the relation with the nominal exchange rate. In the special case with a constant period 2 real exchange rate (i.e. purchasing power parity (PPP)) the nominal exchange rate is simply $\exp \left(-\pi_{2}\right)$ and the cost of repaying LC debt is perfectly correlated with the nominal exchange rate. This special case captures the essence of our mechanism. We make the model more realistic by allowing for shocks to the period 2 real exchange rate, which unlike inflation we assume to be realized exogenously. Eqn. (12) shows that if the domestic real exchange rate is appreciated, i.e. $\mathcal{E}_{2}$ is high, then it is relatively inexpensive for the government to repay its FC debt. 


\subsubsection{Lenders and Bond Pricing}

The government borrows from international lenders and debt is priced by international

lenders' first-order conditions. We assume that international lenders consume $C_{t}^{*}$ units of a global consumption good, which differs from the good consumed by domestic agents. We assume international lenders maximize time-separable CRRA preferences with risk aversion $\gamma^{*}$ and time discount rate $\delta^{*}$ over their own real consumption $C_{t}^{*}$

$$
U^{*}\left(C_{t}^{*}\right)=\frac{\left(C_{t}^{*}\right)^{1-\gamma^{*}}}{1-\gamma^{*}}
$$

We further assume that in period 1 international lenders are exogenously endowed with one unit of the global consumption good and in period 2 with $X_{2}^{*}=\exp \left(x_{2}^{*}\right)$ units of the global consumption good. Because the domestic economy is assumed to be small, international lenders' bond holdings are negligible in equilibrium and their consumption equals their endowment in equilibrium, so $C_{1}^{*}=1$ and $C_{2}^{*}=\exp \left(x_{2}^{*}\right)$.

International lenders' SDF, $M_{2}^{*}$, equals their discounted marginal utility from an additional unit of the global consumption good in period 2 divided by their marginal utility in period 1:

$$
M_{2}^{*}=\delta^{*} \frac{U^{*^{\prime}}\left(C_{2}^{*}\right)}{U^{*^{\prime}}\left(C_{1}^{*}\right)}=\delta^{*} \exp \left(-\gamma^{*} x_{2}^{*}\right) .
$$

The international lenders' SDF is hence exogenous to the government's inflation and debt portfolio policy.

International lenders' first-order conditions over bond holdings imply standard asset pricing Euler equations. Specifically, bond prices must equal the expected real global consumption units that each bond pays discounted at international lenders' SDF $M_{2}^{*}$ :

$$
\begin{aligned}
Q^{L C} & =\mathbb{E}\left[M_{2}^{*} \exp \left(-\pi_{2}\left(X_{2}\right)\right) \mathcal{E}_{2}\right] \\
Q^{F C} & =\mathbb{E}\left[M_{2}^{*}\right]=1 / R^{*}
\end{aligned}
$$

To understand the LC bond price, note that the LC bond pays $\exp \left(-\pi_{2}\left(X_{2}\right)\right)$ units of the domestic consumption good, which international lenders convert into $\exp \left(-\pi_{2}\left(X_{2}\right)\right) \mathcal{E}_{2}$ units of the global consumption good. It is clear from Eqn. (15) that LC bond prices are endogenous to the government's inflation policy. 


\subsubsection{Shocks}

We assume that domestic output $X_{2}$ is log-normally distributed:

$$
X_{2}=\bar{X} \exp \left(x_{2} / \bar{X}\right), \bar{X}=1+\bar{D}
$$

where $x_{2}$ has a loading, $\lambda^{x, x *}$, on the international output and is also subject to an independent shock, $\eta_{2}$ :

$$
\begin{aligned}
& x_{2}=\lambda^{x, x^{*}} x_{2}^{*}+\eta_{2}, \\
& x_{2}^{*} \sim N\left(0,\left(\sigma^{*}\right)^{2}\right), \eta_{2} \sim N\left(0, \sigma_{\eta}^{2}\right) .
\end{aligned}
$$

We denote the standard deviation of $x_{2}^{*}$ by $\sigma^{*}$ and the standard deviation of $x_{2}$ by $\sigma_{x}$. Given that we have CRRA preferences, the correlation between domestic and international agents' marginal utility will be a function of the correlation of their endowment processes. ${ }^{19}$ Normalizing by $\bar{X}$ ensures that $C_{2}$ is centered around 1 for a government that borrows entirely in FC.

We assume that the real exchange rate is distributed according to:

$$
\begin{aligned}
& \mathcal{E}_{2}=\exp \left(\varepsilon_{2}-\frac{1}{2} \sigma_{\varepsilon}^{2}\right) \\
& \varepsilon_{2}=\lambda^{\varepsilon, x^{*}} x_{2}^{*}+e_{2}, \quad e_{2} \sim N\left(0, \sigma_{e}^{2}\right)
\end{aligned}
$$

where the parameter $\lambda^{\varepsilon, x^{*}}$ is the loading of the real exchange rate on international output, and $e_{2}$ captures the idiosyncratic component uncorrelated with international output. The realizations of $x_{2}^{*}, \eta_{2}$, and $e_{2}$ are exogenous and uncorrelated. Real exchange rate shocks are included to make the model more realistic, but are not central to our proposed mechanism.

The Jensen's inequality term in (20) ensures that the real exchange rate equals one in expectation. Real exchange rate fluctuations can be microfounded if international lenders and domestic consumers consume different bundles of goods and international lenders experience preference shocks over the good produced by the domestic economy, as in Gabaix and Maggiori (2015). We formalize the assumptions on preferences and shocks that microfound (20) and (21) in Appendix B.1.

\footnotetext{
${ }^{19}$ As documented in the literature, cross-country correlations of output are higher than cross-country correlations of consumption (Colacito et al. 2018). Colacito et al. (2018) demonstrate that with long-run risks, the correlation of SDFs across countries does not need to be bounded by the correlation of output. However, such an extension is beyond the scope of our static model.
} 
Figure 4: Model Timeline

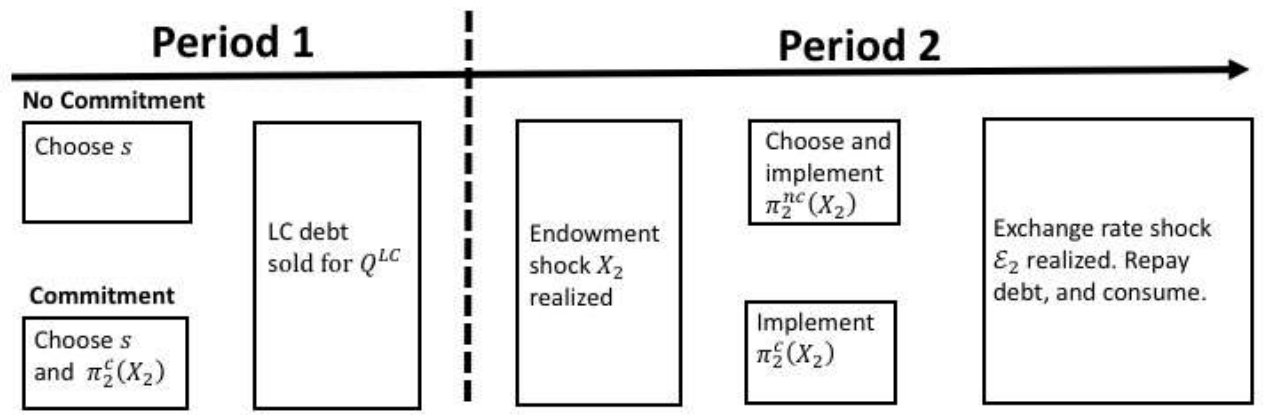

Note: This figure shows the timing of the government's problem without commitment and with commitment.

\subsubsection{Government Problem without Commitment}

Figure 4 depicts the timeline of our model. The government without commitment has two endogenous choice variables - the LC debt share, $s$, and discretionary inflation policy, $\pi_{2}^{n c}\left(X_{2}\right)$. At the beginning of period 2, it chooses inflation after observing domestic output, taking the debt composition and LC bond prices as given. We assume that the no-commitment government chooses inflation after observing domestic output, but before the real exchange rate is realized. In period 2, the no-commitment government's problem is to choose $\pi_{2}^{n c}\left(X_{2}\right)$ to maximize domestic consumer welfare taking the LC debt share, $s$, and bond prices as given:

$$
\max _{\pi_{2}^{n c}\left(X_{2}\right)} \mathbb{E}\left[U\left(C_{2}, \pi_{2}\right) \mid s, Q^{L C}, X_{2}\right]
$$

The government chooses the inflation rate $\pi_{2}^{n c}\left(X_{2}\right) \in \mathbb{R}$ to maximize (22) subject to the budget constraint (9) after having observed the realization for domestic output $X_{2}$. $\mathbb{E}\left[\cdot \mid s, Q^{L C}, X_{2}\right]$ denotes the expectation over $\mathcal{E}_{2}$, taking $s, Q^{L C}$ and $X_{2}$ as given.

In period 1 , the no-commitment government chooses the LC debt share, $s \in[0,1]$, to maximize expected domestic consumer utility while rationally anticipating its own future choice of $\pi_{2}^{n c}\left(X_{2}\right)$. The no-commitment government's problem in period 1 is:

$$
\max _{s \in[0,1]} \mathbb{E}\left[U\left(C_{2}, \pi_{2}\right)\right]
$$

subject to the period 1 borrowing requirement (7), the period 2 budget constraint (9), the bond pricing Eqn. (15), and period 2 inflation policy (22). The expectation in (23) is over $X_{2}$ and $\mathcal{E}_{2}$. 


\subsubsection{Government Problem with Commitment}

A government with commitment sets its inflation policy function $\pi_{2}^{c}\left(X_{2}\right)$ before its debt is priced and sold to international lenders and before $X_{2}$ is realized, as shown in the timeline in Figure 4. It chooses an ex ante function for inflation that is allowed to depend on the future state of domestic output, $\pi_{2}^{c}\left(X_{2}\right)$, and its LC debt share, $s$, to maximize domestic consumer welfare anticipating the endogenous effect on LC bond prices:

$$
\max _{\pi_{2}^{c}\left(X_{2}\right), s} \mathbb{E}\left[U\left(C_{2}, \pi_{2}\right)\right]
$$

where $\mathbb{E}$ denotes the expectation over $X_{2}$ and $\mathcal{E}_{2}$. The inflation policy function $\pi_{2}^{c}\left(X_{2}\right)$ is chosen from the space of functions of $X_{2}$, and $s$ is chosen from the unit interval [0,1], subject to the period 1 borrowing requirement (7), the budget constraint (9), and the bond pricing Eqn. (15). Unlike the no-commitment government, when the commitment government chooses its inflation policy it therefore internalizes the effect of this policy on the bond pricing Eqn. (15).

\subsection{First-Order Conditions}

\subsubsection{Optimal Inflation Policy without Commitment}

The first-order condition for the optimal inflation policy of the no-commitment government is given by:

$$
\underbrace{\alpha \pi_{2}^{n c}\left(X_{2}\right)}_{\text {Deadweight Cost }}=\underbrace{\mathbb{E}\left[U^{\prime}\left(C_{2}^{n c}\right) \frac{\partial C_{2}^{n c}}{\partial \pi_{2}^{n c}} \mid X_{2}\right]}_{\text {Static Gain }} .
$$

The no-commitment government optimally inflates until the marginal deadweight cost of higher inflation (left-hand side of the equation) equals the marginal consumption utility from inflating away the LC debt (right-hand side of the equation). Here, $\frac{\partial C_{2}^{n c}}{\partial \pi_{2}}=D^{L C} \exp \left(-\pi_{2}\left(X_{2}\right)\right) \geq 0$ captures the increase in consumption arising from a reduction in the real value of LC debt repayments. The first-order condition (25) makes clear that the inflation cost, $\alpha$, is needed because otherwise the optimal inflation problem would not be well-defined.

This equation immediately shows that a no-commitment government chooses countercyclical inflation, i.e. higher inflation when domestic output is low, because the marginal utility of domestic consumption, $U^{\prime}\left(C_{2}^{n c}\right)$, tends to be high when domestic output is low. The right-hand side of Eqn. (25) is conditional on $X_{2}$ because the government chooses inflation $\pi_{2}^{n c}\left(X_{2}\right)$ after domestic output $X_{2}$ is realized but without observing the real exchange rate 
shock $\mathcal{E}_{2}$ or international output $X_{2}^{*}$, and therefore the no-commitment government cannot condition its inflation policy on international output or real exchange rate innovations.

\subsubsection{Optimal Inflation Policy with Commitment}

The first-order condition for the optimal inflation policy of the government with commitment is more complex, as this government takes into account how its inflation choices affect the pricing of its LC debt. Defining the probability density function of $X_{2}$ as $f\left(X_{2}\right)$, the firstorder condition takes the following form:

$$
\underbrace{\alpha \pi_{2}^{c}\left(X_{2}\right)}_{\text {Deadweight Cost }}=\underbrace{\mathbb{E}\left[U^{\prime}\left(C_{2}^{c}\right) \frac{\partial C_{2}^{c}}{\partial \pi_{2}^{c}} \mid X_{2}\right]}_{\text {Static Gain }}+\underbrace{\frac{1}{f\left(X_{2}\right)} \frac{d Q^{L C}}{d \pi_{2}^{c}\left(X_{2}\right)} \mathbb{E}\left[U^{\prime}\left(C_{2}^{c}\right) \frac{\partial C_{2}^{c}}{\partial Q^{L C}}\right]}_{\text {Dynamic Cost }} .
$$

The first two terms of the commitment government's first-order condition (26) are identical to the no-commitment government's first-order condition (25), capturing the static trade off between the deadweight cost of higher inflation and the gain in marginal consumption utility from inflating away the debt. The final term, the dynamic cost, is only present for the government with commitment.

The dynamic cost captures how additional inflation in state $X_{2}$ affects domestic welfare across all states in the second period. The final component, $\left(U^{\prime}\left(C_{2}^{c}\right) \frac{\partial C_{2}^{c}}{\partial Q^{L C}}\right)$, captures the effect of a change in the bond price on consumption, scaled by the marginal utility of consumption in that state. The first component $\left(\frac{1}{f\left(X_{2}\right)} \frac{d Q^{L C}}{d \pi_{2}^{c}}\right)$, captures the effect of an increase in inflation in state $X_{2}$ on the bond price, scaled by the probability of the state occurring. Using the expression for the bond price in Eqn. (15), we see that

$$
\frac{1}{f\left(X_{2}\right)} \frac{d Q^{L C}}{d \pi_{2}^{c}}=-\exp \left(-\pi_{2}^{c}\left(X_{2}\right)\right) \mathbb{E}\left[M_{2}^{*} \mathcal{E}_{2} \mid X_{2}\right]<0 .
$$

Because the international lenders' SDF is correlated with domestic marginal consumption utility, the international lenders' SDF tends to be high when $X_{2}$ is low. ${ }^{20}$ Therefore, Eqn. (27) indicates that increasing inflation in a low domestic output state is particularly costly for the LC bond price. This is the risk-premium channel. If lenders were risk-neutral and the real exchange rate were constant (i.e. PPP holds), this term would be proportional to $-\exp \left(-\pi_{2}^{c}\left(X_{2}\right)\right)$, meaning that the government would face the same effect on the bond price from additional inflation in any state of the world. This would still lead a government with commitment to refrain from an average inflation bias (i.e. the type studied in Barro and

\footnotetext{
${ }^{20}$ In general, the correlation between $\mathbb{E}\left[M_{2}^{*} \mathcal{E}_{2} \mid X_{2}\right]$ and domestic output will depend on international lenders' coefficient of risk aversion, the loading of the domestic economy on global output, and the cyclicality of the real exchange rate.
} 
Gordon (1983)). However, the more highly correlated is the lenders' SDF with domestic output, the more the government with commitment refrains from raising inflation in bad states in order to avoid lowering domestic welfare in every state. Later in Section 3.3, we will derive closed-form solutions for optimal inflation policy for a simple case to gain further intuition.

\subsubsection{Optimal LC Debt Share}

To characterize the governments' choice of the currency composition of debt, we take the first derivative of the objective function with respect to the LC debt share $s$ :

$$
\begin{aligned}
\frac{d \mathbb{E} U\left(C_{2}, \pi_{2}\right)}{d s}= & -\alpha \mathbb{E}\left[\pi_{2} \frac{d \pi_{2}}{d s}\right]-\frac{\bar{D}}{R^{*}} \mathbb{E}\left[U^{\prime}\left(C_{2}\right)\left(R_{2}^{L C}-R_{2}^{F C}\right)\right] \\
& -\frac{s \bar{D}^{*}}{R^{*}} \mathbb{E}\left[U^{\prime}\left(C_{2}\right)\left(\frac{d R_{2}^{L C}}{d s}\right)\right]
\end{aligned}
$$

Eqn. (28) holds for both commitment and no-commitment governments, albeit with different inflation policy functions and therefore a different pattern of state-contingent domestic consumption. We do not allow governments to hold net long positions in either type of debt and therefore restrict the LC share to the interval between 0 and 1. For an interior choice for the LC debt share, the derivative (28) must equal zero. The derivative is positive if the upper bound $s=1$ (all LC debt) is binding and negative if the lower bound $s=0$ (all FC debt) is binding.

The government's incentive to shift towards more LC debt on the margin depends on three terms: First, the marginal change in the deadweight cost of inflation from borrowing more in LC. The second term captures the competing forces from the state-contingency of inflation, which are the main focus of our analysis. On the one hand, if international lenders require a higher $\mathrm{LC}$ bond risk premium to compensate for the state-contingency of LC bond payoffs, this raises the domestic government's real cost of repaying LC debt and makes LC debt issuance unattractive. On the other hand, if inflation state-contingency is such that the real cost of repaying LC debt is low in states when domestic marginal utility of consumption is high, this makes LC debt issuance attractive because it provides hedging benefits to domestic consumers. Third, the endogenous response of the LC bond risk premium to the government's debt currency choice, as lenders rationally anticipate that borrowing in LC changes the government's incentive to generate more counter-cyclical inflation. All three

terms tend to push the government without commitment towards FC debt compared to the government with commitment. Naturally, the risk premium forces will be shut off if lenders 
have zero risk aversion, as in Calvo and Guidotti (1990).

\subsection{Analytical Special Case}

Before turning to the quantitative evaluation, we analytically characterize a special case. This allows us to clearly distinguish our risk premium-centered mechanism from the classic Barro and Gordon (1983) inflation bias and provides intuition for the distinct mechanism in our model. For simplicity, we assume that the real exchange rate is constant $\left(\mathcal{E}_{1}=\mathcal{E}_{2}=1\right)$ , and that there is only a global endowment shock $\left(x_{2}=x_{2}^{*}\right) \cdot{ }^{21}$ First, we characterize the inflation policies for the commitment and no-commitment governments for a given LC debt share $s$, and then we discuss the trade-off between LC and FC debt. Since the purpose of the analytic solutions is to illustrate the key features of the equilibrium and we later solve the model numerically, we use a simple log-linearization strategy to convey this intuition. We relegate the algebra behind these approximations to Appendix B.4.

\subsubsection{Optimal Inflation Policy}

We now present an approximate analytical solution for the commitment and no-commitment governments' optimal inflation policy at a given LC debt share $s$. We collect the inflation policy functions for the two types of governments in the following proposition:

Proposition 1. Assume that the real exchange rate is constant $\left(\mathcal{E}_{2}=1\right)$ and that there is only one global endowment shock $\left(x_{2}=x_{2}^{*}\right)$. Taking first-order log-linear Taylor approximations of the inflation first-order conditions (25) and (26) around $\left(c_{2}=0, \pi_{2}=0\right)$, and imposing that lenders' expectations are rational, gives log-linear approximate solutions for $\pi_{2}^{n c}\left(X_{2}\right)$ and $\pi_{2}^{c}\left(X_{2}\right)$ :

$$
\begin{aligned}
\pi_{2}^{n c}\left(X_{2}\right) & =\frac{s \bar{D}}{\alpha}-\gamma \frac{s \bar{D}}{\alpha} x_{2} \\
\pi_{2}^{c}\left(X_{2}\right) & =\left(\gamma^{*}-\gamma\right) \frac{s \bar{D}}{\alpha} x_{2}
\end{aligned}
$$

We substitute the exact dependence of the LC bond price on state-contingent inflation (27) into the commitment government's first-order condition (26) and then take a standard log-linear first-order approximation (e.g. Campbell (1994)). ${ }^{22}$ This log-linearization proce-

\footnotetext{
${ }^{21}$ The analytical model solution takes the same form when we allow for a separate domestic output shock, except that international risk aversion needs to be scaled by global-domestic output comovement.

${ }^{22}$ To keep the analytical expressions in Proposition 1 tractable, we show only the lowest-order terms in the debt-to-GDP ratio $\bar{D}$, which dominate when the debt-to-GDP ratio is small.
} 
dure allows us to preserve the risk premium. ${ }^{23}$

Proposition 1 shows two important differences between the policies chosen by commitment and no-commitment governments. First, comparing the intercepts shows that a government without commitment chooses positive inflation on average, whereas a government with commitment finds it optimal to choose zero inflation on average. Because a government with commitment recognizes that its choice of inflation is priced in ex ante, it internalizes that a choice of non-zero average inflation strictly reduces welfare.

The second difference between these two policy functions - and the difference that distinguishes our analysis from that of Barro and Gordon (1983) - is how inflation comoves with domestic output, $x_{2}$. The no-commitment government's inflation policy loads onto domestic output with a negative coefficient that is proportional to $-\gamma$. By contrast, the commitment government's inflation policy loads onto domestic output with a coefficient that is proportional to $\gamma^{*}-\gamma$. At a given LC debt share, the commitment government therefore optimally chooses a less counter-cyclical inflation policy than the no-commitment government, and the difference in cyclicality increases with international lender risk aversion $\gamma^{*}$. The difference arises because the government with commitment internalizes that if it inflates in states when international lenders' marginal consumption utility is high, this disproportionately lowers the price that its LC bonds sell for, as seen in Eqn. (27).

\subsubsection{Trade-Offs Between LC and FC Debt}

Having characterized how the two types of governments optimally choose their inflation policy conditional on a given LC debt share, we now turn to the trade-offs faced by these governments in deciding how much to borrow in their own currency. ${ }^{24}$ There are two costs faced by a government without commitment when it borrows in its own currency: a high average inflation rate and a higher risk premium. The average inflation rate is simple. Taking the unconditional expectations of the inflation policy functions in Eqns. (29) and (30), we

\footnotetext{
${ }^{23} \mathrm{An}$ alternative approximation approach would be to take a log-linear approximation of the international lenders' Euler equation and then substitute an approximate relation for $\frac{1}{f\left(X_{2}\right)} \frac{d Q^{L C}}{d \pi_{2}^{C}}$ into the domestic government's first-order condition. However, this alternative approach misses the effect of LC bond risk premia that is at the heart of our mechanism.

${ }^{24}$ We do not explicitly solve for the optimal LC debt share because approximate log-linear solutions are not appropriate for constrained optimization problems. Instead, we use our approximate optimal inflation policies to intuitively demonstrate the main trade-offs faced by governments when they choose the currency composition of their debt.
} 
have:

$$
\begin{gathered}
E\left(\pi_{2}^{n c}\right)=\frac{s \bar{D}}{\alpha}, \\
E\left(\pi_{2}^{c}\right)=0 .
\end{gathered}
$$

In this economy, an average inflation bias is a pure loss: it is priced in ex ante and so provides no consumption benefit in equilibrium. The no-commitment government correctly anticipates that its average inflation bias increases with the share of debt denominated in $\mathrm{LC}, s$, incentivizing it to borrow in FC instead. This is the classic inflationary bias of Barro and Gordon (1983) and Calvo and Guidotti (1990) and not new to our analysis. Formally, this force enters the optimal LC debt choice through the first term on the right-hand side of Eqn. (28).

However, our economy features an additional new force that makes LC debt costly for a government without commitment: the risk premium. To better understand this force, we note that in the special case with log-linear inflation policies as in Eqns. (29) and (30) the LC bond price simplifies to:

$$
Q^{L C}=\frac{1}{R^{*}} \exp \left(-\mathbb{E} \pi_{2}+\frac{1}{2} \operatorname{Var}\left(\pi_{2}\right)+\gamma^{*} \operatorname{Cov}\left(\pi_{2}, x_{2}\right)\right) .
$$

Expected mean inflation, the expected inflation variance, and the expected covariance between output and inflation are all the rational expectations of the international lenders at the time the debt is sold and priced. We define the LC bond risk premium as the log expected real LC bond return in excess of the log global FC interest rate, analogously to our empirical analysis. In this special case, the LC bond risk premium simplifies to:

$$
R P=\log \mathbb{E} \frac{\exp \left(-\pi_{2}\right)}{Q^{L C}}-\log R^{*}=-\gamma^{*} \operatorname{Cov}\left(\pi_{2}, x_{2}\right)
$$

Substituting in the inflation policy functions in Eqns. (29) and (30), we have:

$$
\begin{aligned}
R P^{n c} & =\gamma^{*} \gamma \frac{s \bar{D}}{\alpha} \sigma_{x}^{2} \\
R P^{c} & =\gamma^{*}\left(\gamma-\gamma^{*}\right) \frac{s \bar{D}}{\alpha} \sigma_{x}^{2}
\end{aligned}
$$

LC bond risk premia affect the optimal debt currency choice through two channels. First, at a given level of the LC debt share, $s$, the LC bond risk premium paid by a government without commitment (Eqn. (35)) is greater than that paid by a government with commit- 
ment (Eqn. (36)), conditional on international lender risk aversion being non-zero $\left(\gamma^{*}>0\right)$. The higher LC bond risk premium incentivizes the no-commitment government to tilt away from LC borrowing, because it understands that average real domestic consumption declines with the product of the LC bond risk premium and the share of debt in LC. ${ }^{25}$ Second, taking the derivative with respect to $s$ of Eqns. (35) and (36) shows that the LC bond risk premium paid by the government without commitment increases faster with $s$, again conditional on international lender risk aversion being non-zero $\left(\gamma^{*}>0\right)$. A no-commitment government's tendency to generate counter-cyclical inflation increases with the amount it has borrowed in LC, leading lenders to charge higher LC bond risk premia ex ante. The no-commitment government therefore has an incentive to reduce its LC borrowing to limit its own future incentive to generate counter-cyclical inflation, thereby lowering the LC bond risk premium ex ante. ${ }^{26}$

To summarize, the analytical solutions for this special case suggest that governments without commitment optimally choose more counter-cyclical inflation than governments with commitment. Further, governments without commitment face stronger incentives to borrow in $\mathrm{FC}$, due to endogenous LC bond risk premia and deadweight cost of anticipated inflation. If countries differ in their ability to commit to future monetary policy, this channel can therefore qualitatively generate our main empirical finding that countries with highly counter-cyclical inflation tend to borrow mostly in FC. We next turn to a quantitative analysis of how these forces determine the equilibrium relationship between the currency composition of sovereign debt and the cyclicality of inflation.

\section{Quantitative Evaluation}

This section evaluates the full model quantitatively. We calibrate the model separately for emerging markets (EM) and developed markets (DM), with the difference being that EMs are modeled as as a no-commitment government and DMs are modeled as a commitment government. We solve the model numerically using global solution methods to account for risk premia. For details of the numerical solution see Appendix B.5.

\footnotetext{
${ }^{25}$ Formally, this channel changes the incentive to borrow with LC debt through the second term on the right-hand side of Eqn. (28).

${ }^{26}$ Formally, this channel changes the incentive to borrow with LC debt through the third term on the right-hand side of Eqn. (28).
} 


\subsection{Bond and Stock Returns}

In order to compare bond-stock betas in the model and in the data, we need to model bond

and stock returns. We model log excess LC bond return innovations as revisions to log bond prices from period 1 to period 2 :

$$
x r_{i, 2}^{L C}-\mathbb{E} x r_{i, 2}^{L C}=-\left(\pi_{i, 2}-\mathbb{E} \pi_{i, 2}\right)
$$

where $i=E M$ or $i=D M$. Model LC bond excess returns are currency hedged, analogously to the empirical analysis in Section 2. We model stocks simply as an asset class whose $\log$ dividends are proportional to $\log$ domestic output. In order to focus on the role of government bonds as a tool to hedge domestic consumption, we assume that stocks cannot be traded across borders. Specifically, we model log domestic equity return innovations as proportional to log domestic output:

$$
x r_{i, 2}^{m}-\mathbb{E} x r_{i, 2}^{m}=\lambda^{m, x}\left(x_{i, 2}-\mathbb{E} x_{i, 2}\right)
$$

In our calibration, we set the coefficient $\lambda^{m, x}$ to be consistent with the data. Regressing quarterly local equity excess returns onto log domestic output gives a coefficient of 4 , averaged across EMs and DMs, as listed in Table 5. The estimated coefficient for EMs is not statistically different from the one for DMs at the $95 \%$ level, so we use the average in the calibration for both EMs and DMs.

With Eqns. (37) and (38) we obtain a simple relationship between model bond-stock betas and inflation-output betas:

$$
\begin{aligned}
\beta^{\text {model }}\left(\text { bond }_{i}, \text { stock }_{i}\right) & =-\frac{1}{\lambda^{m, x}} \beta^{\text {model }}\left(\pi_{i}, x_{i}\right) \\
\beta^{\text {model }}\left(\pi_{i}, x_{i}\right) & =\frac{\operatorname{Cov}\left(\pi_{i, 2}, x_{i, 2}\right)}{\sigma_{i, x}^{2}}
\end{aligned}
$$

The relation in Eqn. (39) captures the intuition that bond-stock betas have the opposite sign from inflation-output betas and are compressed towards zero, because stocks are more volatile than output. Our two-period model does not allow for time-varying risk premia, which tend to amplify bond-stock correlations (Campbell et al., 2019). 


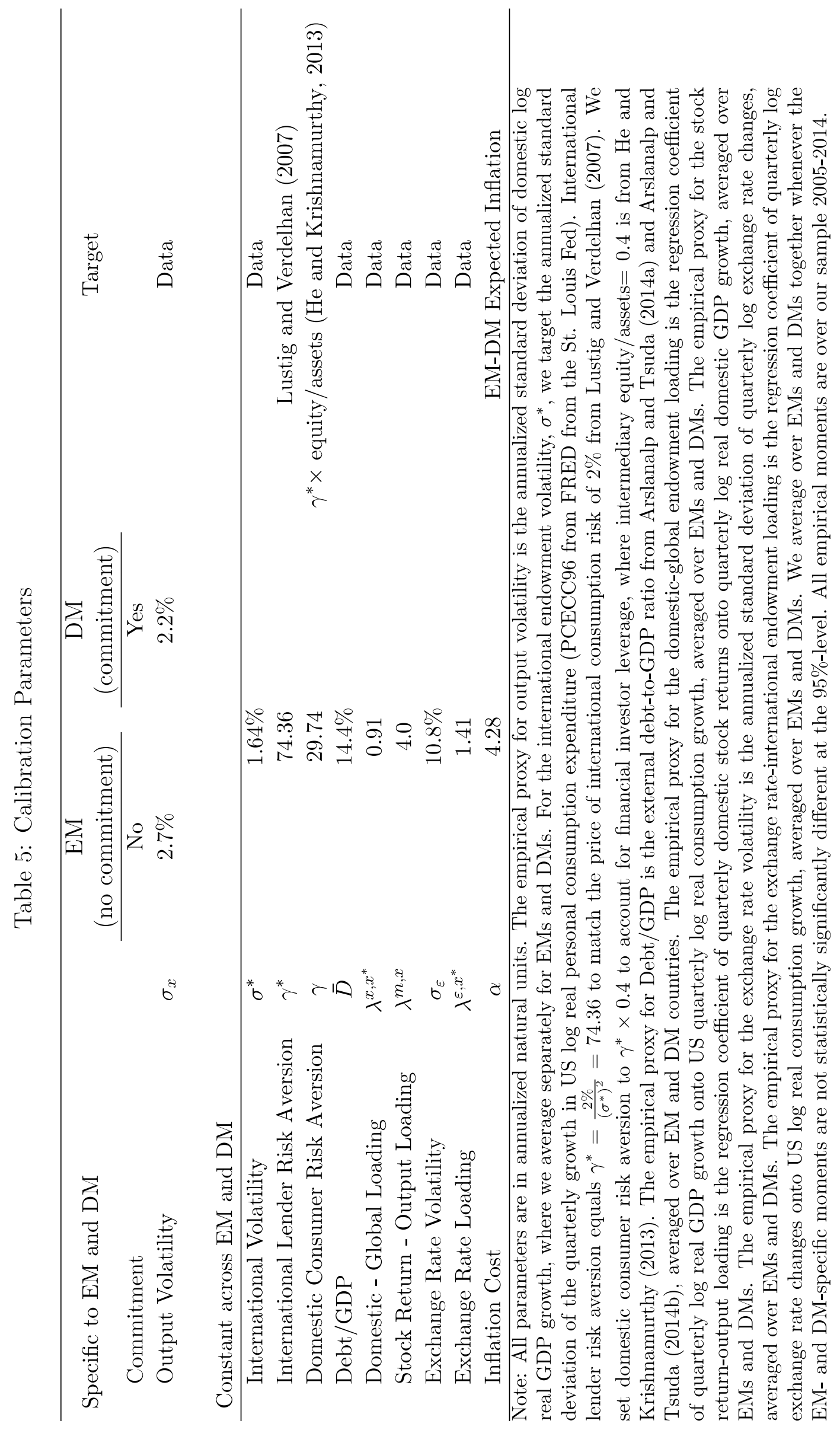




\subsection{Calibration}

EM (no commitment) and DM (commitment) calibrations differ along two dimensions. Most importantly, we assume that developed market governments have commitment and EM governments do not. Second, we match EM and DM output volatilities separately to the data, because EMs have significantly higher output volatility in the data.

To highlight the differences between EMs and DMs that arise from differences in credibility, we choose equal parameter values for EM and DM calibrations whenever this is empirically plausible. In particular, we use equal parameter values when the corresponding EM and DM moments in the data are not statistically different at the $95 \%$ level. Since the international lender should be the same for both countries, we choose the same lender risk aversion, and international endowment volatility for both calibrations. We set the international endowment volatility in the model to $1.64 \%$ to match the annualized standard deviation of the quarterly growth in US log real personal consumption expenditure. ${ }^{27}$ We set international lenders' risk aversion to $\gamma^{*}=\frac{2 \%}{\left(\sigma^{*}\right)^{2}}=74.36$ to match the price of international consumption risk of $2 \%$ from Lustig and Verdelhan (2007). While this risk aversion coefficient may at first appear high, it is not unusual in the literature seeking to explain the equity premium (Campbell and Cochrane (1999); Lustig and Verdelhan (2007)). One way to interpret this high coefficient of risk aversion is by noting that international lenders in sovereign debt tend to be intermediaries whose risk aversion is amplified by financial leverage (Morelli et al. (2019)). We set domestic consumer risk aversion to be consistent with that of international lenders, assuming that international lenders' are levered with an intermediary equity to total assets ratio of 0.4 as in He and Krishnamurthy (2013). We therefore set domestic consumer risk aversion to $\gamma=29.74\left(=\gamma^{*} \times 0.4\right)$.

We set the debt-to-GDP ratio to $\bar{D}=14.4 \%$ to match the share of external debt to GDP in Arslanalp and Tsuda (2014a,b), averaged across EMs and DMs. EMs and DMs have similar ratios of external debt-to-GDP (13.2\% for EMs and $16.1 \%$ for DMs) and the difference is not statistically significant, so we use the average for both calibrations.

We set the loading of local output onto international consumption to $\lambda^{x, x^{*}}=0.91$ to match the regression coefficient of quarterly local log real GDP growth onto log real US consumption growth, averaged across EMs and DMs. The loadings in the data are only slightly lower for EMs (0.87) than for DMs (0.97) and the difference is not statistically significant, so we use the average for both calibrations.

We set real exchange rate volatility to the standard deviation of quarterly changes in the local currency-USD exchange rate, $\sigma_{\varepsilon}=10.8 \%$, after averaging exchange rate volatilities

\footnotetext{
${ }^{27}$ We use the series PCECC96 from FRED from the St. Louis Fed. We compute the standard deviation over our sample 2004-2015.
} 
of 11 developed markets and 17 emerging markets in our sample with equal weights. We estimate very similar exchange rate volatilities for EMs (10.4\%) and DMs (11.4\%) and the difference is not statistically significant.

We set the loading of the real exchange rate onto US consumption to $\lambda^{\varepsilon, x^{*}}=1.41$ to match the regression coefficient of quarterly log exchange rate changes onto log US real consumption growth, averaged across EMs and DMs. Because exchange rates are about seven times as volatile as US real consumption growth, this loading implies a correlation between the real exchange rate and US consumption growth of $\operatorname{Corr}\left(\varepsilon_{2}, x_{2}^{*}\right)=\lambda^{\varepsilon, x^{*}} \times \frac{\sigma^{*}}{\sigma_{\varepsilon}}=0.21$, in line with the real exchange rate-consumption correlation of 0.20 reported in Itskhoki and Mukhin (2019). Finally, we set the inflation cost parameter, $\alpha$, equal across EMs and DMs and choose it to match the average inflation difference between EMs and DMs. ${ }^{28}$

\section{$4.3 \quad$ Results}

Table 6 compares calibrated model moments with the data. By construction, the model matches exactly the EM-DM difference in average inflation of $2.20 \% .^{29}$

The model also matches several moments that we did not target in our calibration. Most importantly, the model implies a similarly downward-sloping cross-country relation between bond-stock betas and LC debt shares as in the data. The model-implied EM LC debt share is $39 \%$, compared to $55 \%$ in the data. The model-implied DM LC debt share is substantially higher at $91 \%$, compared to $90 \%$ in the data. Moreover, the model implies that bond-stock betas are substantially higher in EMs than in DMs, with an EM-DM difference in bondstock betas of 0.21 in the model, compared to 0.17 in the data. The model implies that LC debt by EMs has a risk premium that is two percentage points higher than that of DMs. This substantial risk premium differential is entirely due to differences in the inflation risk premium, since real exchange rate correlations with US consumption are equal for EMs and DMs. It also is similar to the risk premium differential of 1.62 percentage points in the data.

Having calibrated the model, we now turn to the optimal government policy for EMs

\footnotetext{
${ }^{28}$ With the ability to commit to future inflation, average model DM inflation is at its optimal level and independent of $\alpha$. For this reason we cannot choose separate inflation cost parameters to separately match DM and EM average inflation rates. We show in Appendix B.7.3 that calibration moments are robust to a wide range of values for $\mathrm{DM} \alpha$.

${ }^{29}$ We think of the model implication that DM average inflation equals zero as empirically plausible, because zero represents the optimal inflation level in the model. Similarly, DM inflation appears close to optimal in the data, taking into account that in reality there are reasons to optimally target a small but positive inflation rate. One reason for a positive inflation target is if measured inflation tends to overstate true inflation due to quality improvements and index substitutions (Bernanke and Mishkin 1997). Other reasons are related to the risk of hitting the zero lower bound (Coibion et al. 2012). Because a positive optimal rate of inflation should lift both DM and EM inflation equally, our calibration targets the difference in EM and DM inflation.
} 
Table 6: Empirical and Model Moments

\begin{tabular}{|c|c|c|c|c|c|c|}
\hline & \multicolumn{2}{|c|}{$\begin{array}{c}\text { EM } \\
\text { (no commitment) }\end{array}$} & \multicolumn{2}{|c|}{$\begin{array}{c}\mathrm{DM} \\
\text { (commitment) }\end{array}$} & \multicolumn{2}{|c|}{ EM-DM } \\
\hline & Data & Model & Data & Model & Data & Model \\
\hline Average Inflation & $3.92 \%$ & $2.20 \%$ & $1.73 \%$ & $0.00 \%$ & $2.20 \%$ & $2.20 \%$ \\
\hline Bond-Stock Beta & 0.07 & 0.16 & -0.10 & -0.05 & 0.17 & 0.21 \\
\hline LC Debt Share & 0.55 & 0.39 & 0.90 & 0.91 & -0.35 & -0.52 \\
\hline LC Bond RP & $3.15 \%$ & $4.18 \%$ & $1.53 \%$ & $2.22 \%$ & $1.62 \%$ & $1.96 \%$ \\
\hline
\end{tabular}

Note: All moments are in annualized natural units. Model parameters for the EM and DM calibrations are given in Table 5. Model average inflation is the unconditional average of level inflation. The model bondstock beta is computed according to Eqn. (39). The model LC bond risk premium in percent is computed according to Eqn. (34).

and DMs. Consistent with the analytical special case, the model predicts that EMs, which are modeled as having no commitment, choose more counter-cylical inflation than DMs and a lower share of LC debt, thereby matching the basic relation we documented in the data. Higher international risk aversion shifts bond-stock betas downwards for both EMs and DMs but does not change the qualitative predictions about the difference between EM and DM bond-stock betas, which is the main focus of our analysis.

Figure 5 Panel A shows the LC bond-stock beta as an indicator of the optimal inflation policy against international lender risk aversion on the $\mathrm{x}$-axis. A positive model bond-stock beta corresponds to counter-cyclical inflation via Eqn. (39). We see that model bond-stock betas for EMs are higher than for DMs, as long as international lender risk aversion is nonzero. This is consistent with the analytical results in Proposition 1, where we saw that a government without commitment chooses more counter-cyclical inflation than a government with commitment at a given LC debt share. Here, the results are even stronger and directly speak to our main empirical findings: EM (no commitment) governments implement a more counter-cyclical inflation policy than DM (commitment) governments even though they have a lower LC debt share.

Figure 5 Panel B confirms the intuition from the analytical special case that EMs' lack of commitment leads them to optimally tilt towards FC debt. The risk premia charged by international lenders provide a quantitatively important incentive for EMs to use FC debt, as can be seen from the fact that the EM LC debt share is one when setting international lender risk aversion to zero.

Figure 5 shows that extremely high risk aversion is not necessary to generate a gap between EM and DM LC bond-stock betas. When we assume lenders to be unlevered (indicated with a vertical line at 29.74), the model generates a similarly downward-sloping relation between bond-stock betas and LC debt shares across EMs and DMs, but the overall 
level of bond-stock betas is higher. As lender risk aversion increases beyond domestic agent's risk aversion the gap between EM and DM LC bond-stock betas stabilizes because EMs constrain their incentive to generate counter-cyclical inflation by choosing a lower LC debt share. $^{30}$

Having seen that differences in commitment across EMs and DMs can generate a downwardsloping relation between LC bond-stock betas and LC debt shares qualitatively, we directly compare the model implications to the data. Figure 6 shows that differences in credibility can generate the cross-country relationship between bond cyclicality and the currency composition of sovereign debt documented in the data. The blue solid line is the fitted line of the empirical LC debt share against the bond-stock beta, where we summarize our empirical data into five equal-weighted beta-sorted portfolios and measure the external LC debt share from TIC data. The baseline model counterfactual generates a similarly negative relationship between LC debt shares and bond-stock betas as in the data. ${ }^{31}$

We also show a second counterfactual in Figure 6, which sets international and domestic risk aversion to conventional values from the real business cycle literature $\left(\gamma^{*}=0, \gamma=2\right)$ for the cases of governments with and without commitment. This second counterfactual shows that in the absence of lender risk aversion the model generates an upward sloping relationship between LC debt shares and bond-stock betas, in contrast to the data. Intuitively, when international lenders do not require risk premia even a government with perfect commitment optimally inflates during bad states of the world, thereby using its LC debt as an instrument to optimally reduce the volatility of real domestic consumption. This demonstrates that even though a deadweight cost of inflation $(\alpha)$ along with a lack of commitment can lead governments to tilt their issuance toward FC, these forces alone do not generate our main empirical finding of a downward-sloping relationship between LC debt shares and bond-stock betas. These results therefore illustrate how the combination of limited commitment and risk-averse lenders rationalizes the empirical findings.

\footnotetext{
${ }^{30} \mathrm{DMs}$ optimally choose a small share of FC debt, but the magnitude is negligible. This arises because international lenders require a risk premium on LC debt as compensation for the correlation between the real exchange rate and the international lenders' SDF.

${ }^{31}$ While the model does not provide a formal account of the intermediate portfolios in Figure 6, the correspondence between the data and the fitted model line suggests that we can roughly regard them as average outcomes for countries that randomize between commitment and no commitment.
} 
Figure 5: Optimal Government Policy vs. International Lender Risk Aversion

(A) Model LC Bond-Stock Beta

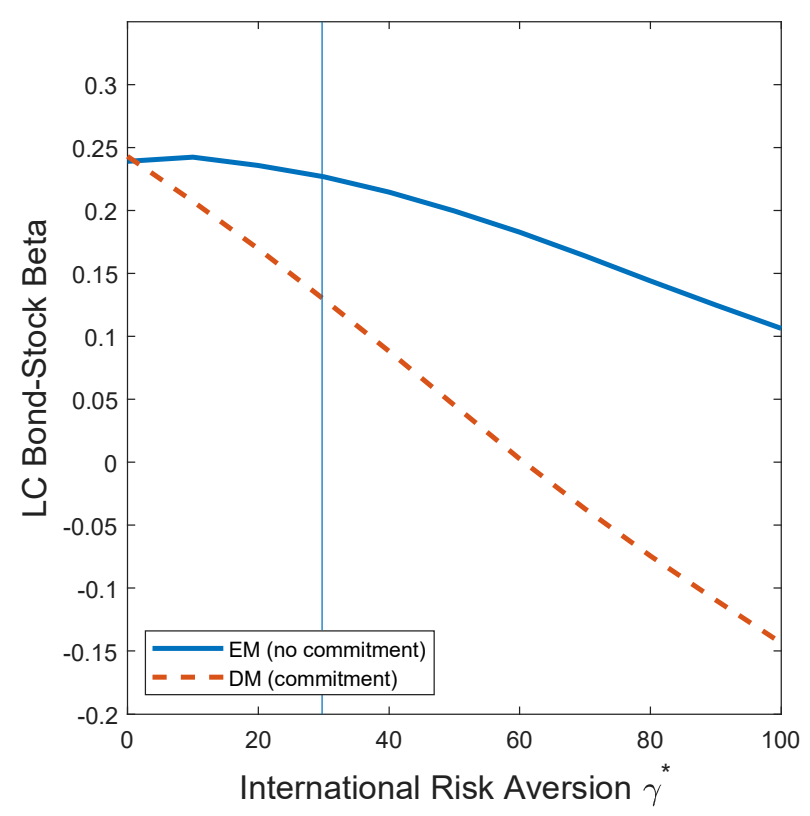

(B) Model LC Debt Share

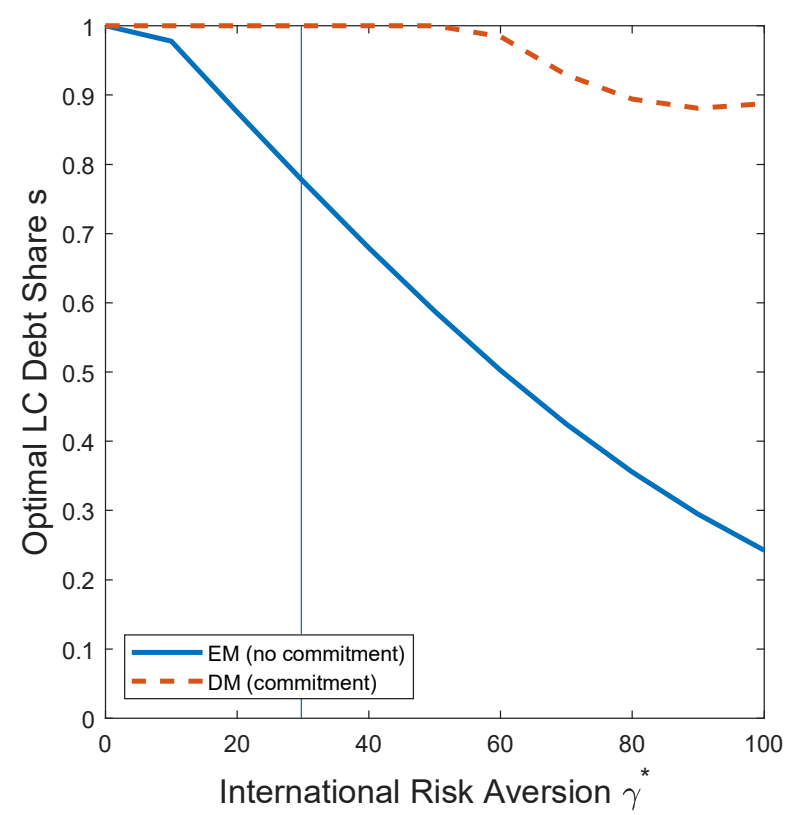

Note: This figure shows the model LC bond-stock beta and the LC debt share for the EM and DM calibrations. The solid blue lines indicate the EM calibration, while the dashed red lines indicate the DM calibration. The model LC bond-stock beta is closely related to the model inflation-output beta via Eqn. (39), and reflects each government's optimally chosen inflation policy. Both panels vary the international lenders' coefficient of risk aversion, $\gamma^{*}$, along the $\mathrm{x}$-axis while holding all other parameters constant at the values shown in Table 5. A vertical line indicates $\gamma^{*}=29.74$ (i.e. equal lender and domestic risk aversion). 
Figure 6: Model and Data

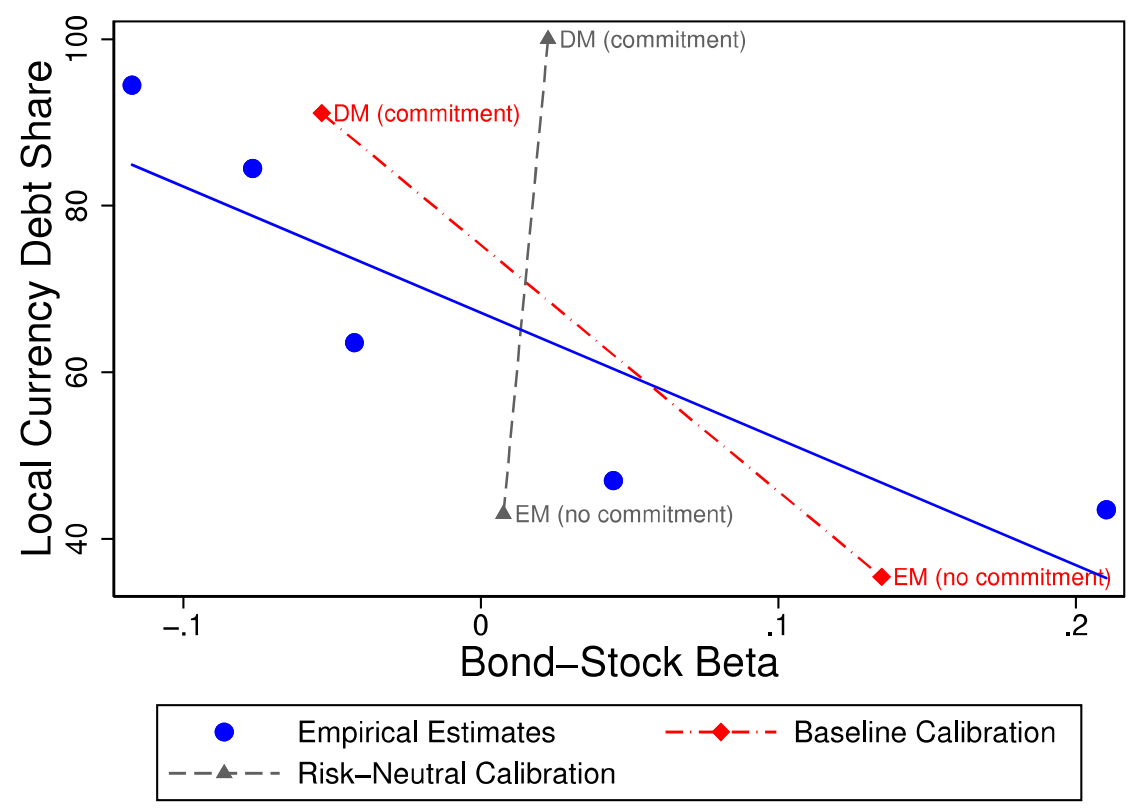

Note: This figure traces out the model bond-stock beta against the LC debt share implied by the EM (no commitment) calibration and the DM (commitment) calibration. The risk-neutral model calibration sets $\gamma^{*}=0$ and $\gamma=2$ and all other parameters as in Table 5. The empirical estimates show the equal-weighted bond-stock betas and external TIC LC debt shares of five beta-sorted portfolios with a trend line.

\section{Conclusion}

This paper provides new evidence that countries that seemingly have the most to gain from borrowing in their own currency do so the least. We explain this new stylized fact with differences in monetary policy credibility, combined with lenders who require risk premia for holding assets that lose value during global downturns. Governments without monetary policy credibility cannot commit against using inflation to overinsure their domestic consumption ex post, so lenders charge a positive risk premium for holding local currency debt. This discourages governments from borrowing in local currency ex ante. Our simple framework demonstrates that including both risk premia and endogenous monetary policy can qualitatively change our assessment of what constitutes optimal government debt management. 


\section{References}

Alfaro, Laura, and Fabio Kanczuk, 2010, Nominal versus indexed debt: A quantitative horse race, Journal of International Money and Finance 29, 1706-1726.

Arslanalp, Serkan, and Takahiro Tsuda, 2014a, Tracking global demand for advanced economy sovereign debt, IMF Economic Review 62, 430-464.

Arslanalp, Serkan, and Takahiro Tsuda, 2014b, Tracking global demand for emerging market sovereign debt, IMF Working Paper No. 14/39 .

Baele, Lieven, Geert Bekaert, and Koen Inghelbrecht, 2010, The determinants of stock and bond return comovements, Review of Financial Studies 23, 2374-2428.

Barro, Robert J, 1979, On the determination of the public debt, Journal of Political Economy 87, 940-971.

Barro, Robert J, 2003, Optimal management of indexed and nominal debt, Annals of Economics and Finance 4, 1-15.

Barro, Robert J, and David B Gordon, 1983, Rules, discretion and reputation in a model of monetary policy, Journal of Monetary Economics 12, 101-121.

Bernanke, Ben S, and Frederic S Mishkin, 1997, Inflation targeting: A new framework for monetary policy?, Journal of Economic Perspectives 11, 97-116.

Bohn, Henning, 1988, Why do we have nominal government debt?, Journal of Monetary Economics $21,127-140$.

Bohn, Henning, 1990a, A positive theory of foreign currency debt, Journal of International Economics 29, 273-292.

Bohn, Henning, 1990b, Tax smoothing with financial instruments, American Economic Review 80, 1217-1230.

Borri, Nicola, and Adrien Verdelhan, 2011, Sovereign risk premia, Working Paper, LUISS Guido Carli University and MIT .

Broner, Fernando A, Guido Lorenzoni, and Sergio L Schmukler, 2013, Why do emerging economies borrow short term?, Journal of the European Economic Association 11, 67-100.

Calvo, Guillermo A, and Pablo E Guidotti, 1990, Credibility and nominal debt: Exploring the role of maturity in managing inflation, IMF Staff Papers 37, 612-635.

Calvo, Guillermo A, and Pablo E Guidotti, 1993, On the flexibility of monetary policy: The case of the optimal inflation tax, Review of Economic Studies 60, 667-687.

Campbell, John Y, 1994, Inspecting the mechanism: An analytical approach to the stochastic growth model, Journal of Monetary Economics 33, 463-506.

Campbell, John Y, 2003, Consumption-based asset pricing, Handbook of the Economics of Finance $1,803-887$.

Campbell, John Y, 2017, Financial Decisions and Markets: A Course in Asset Pricing (Princeton University Press).

Campbell, John Y, and John H Cochrane, 1999, By force of habit: A consumption-based explanation of aggregate stock market behavior, Journal of Political Economy 107, 205-251.

Campbell, John Y, Carolin Pflueger, and Luis M Viceira, 2019, Macroeconomic drivers of bond and equity risks, Working Paper, Harvard University and University of British Columbia .

Campbell, John Y, Robert J Shiller, and Luis M Viceira, 2009, Understanding inflation-indexed 
bond markets, Brookings Papers on Economic Activity 1, 79-138.

Campbell, John Y, Adi Sunderam, and Luis M Viceira, 2017, Inflation bets or deflation hedges? The changing risks of nominal bonds, Critical Finance Review 6, 263-301.

Coibion, Olivier, Yuriy Gorodnichenko, and Johannes Wieland, 2012, The optimal inflation rate in new keynesian models: should central banks raise their inflation targets in light of the zero lower bound?, Review of Economic Studies 79, 1371-1406.

Colacito, Riccardo, and Mariano M Croce, 2011, Risks for the long run and the real exchange rate, Journal of Political Economy 119, 153-181.

Colacito, Riccardo, and Mariano M Croce, 2013, International asset pricing with recursive preferences, Journal of Finance 68, 2651-2686.

Colacito, Riccardo, Max Croce, Steven Ho, and Philip Howard, 2018, BKK the EZ way: International long-run growth news and capital flows, American Economic Review 108, 3416-3449.

Crowe, Christopher, and Ellen E. Meade, 2007, The evolution of central bank governance around the world, Journal of Economic Perspectives 21, 69-90.

David, Alexander, and Pietro Veronesi, 2013, What ties return volatilities to fundamentals and price valuations?, Journal of Political Economy 121, 682-746.

David, Joel M, Espen Henriksen, and Ina Simonovska, 2016, The risky capital of emerging markets, NBER Working Paper wp20769 .

Davison, Anthony Christopher, and D V Hinkley, 1997, Bootstrap Methods and their Application (Cambridge University Press).

Debortoli, Davide, Ricardo Nunes, and Pierre Yared, 2017, Optimal time-consistent government debt maturity, Quarterly Journal of Economics 132, 55-102.

Della Corte, Pasquale, Steven Riddiough, and Lucio Sarno, 2016, Currency premia and global imbalances, Review of Financial Studies 29, 2161-2193.

Díaz-Giménez, Javier, Giorgia Giovannetti, Ramon Marimon, and Pedro Teles, 2008, Nominal debt as a burden on monetary policy, Review of Economic Dynamics 11, 493-514.

Du, Wenxin, and Jesse Schreger, 2016a, Local currency sovereign risk, Journal of Finance 71, 1027-1070.

Du, Wenxin, and Jesse Schreger, 2016b, Sovereign risk, currency risk, and corporate balance sheets, Working Paper, Federal Reserve Board and Harvard Business School .

Duffee, Gregory, 2018, Expected inflation and other determinants of treasury yields, Journal of Finance 73, 2139-2180.

Eichengreen, Barry, and Ricardo Hausmann, 1999, Exchange rates and financial fragility, NBER Working Paper wp7418.

Eichengreen, Barry, and Ricardo Hausmann, 2005, Other People's Money: Debt Denomination and Financial Instability in Emerging Market Economies (University of Chicago Press).

Engel, Charles, and JungJae Park, 2018, Debauchery and original sin: The currency composition of sovereign debt, NBER Working Paper wp24671.

Ermolov, Andrey, 2018, Time-varying risk of nominal bonds: How important are macroeconomic shocks?, Working Paper, Fordham University .

Farhi, Emmanuel, and Matteo Maggiori, 2018, A model of the international monetary system, Quarterly Journal of Economics 133, 295-355.

Gabaix, Xavier, and Matteo Maggiori, 2015, International liquidity and exchange rate dynamics, 
Quarterly Journal of Economics 130, 1369-1420.

Gibbons, Michael R., Stephen A. Ross, and Jay Shanken, 1989, A test of the efficiency of a given portfolio, Econometrica 57, 1121-1152.

Hansen, Lars Peter, and Robert J Hodrick, 1980, Forward exchange rates as optimal predictors of future spot rates: An econometric analysis, Journal of Political Economy 88, 829-853.

Harvey, Campbell R, 1991, The world price of covariance risk, Journal of Finance 46, 111-157.

Hassan, Tarek A, 2013, Country size, currency unions, and international asset returns, Journal of Finance 68, 2269-2308.

Hassan, Tarek A, Thomas M Mertens, and Tony Zhang, 2016, Currency manipulation, NBER Working Paper wp22790 .

He, Zhiguo, and Arvind Krishnamurthy, 2013, Intermediary asset pricing, American Economic Review 103, 732-70.

Itskhoki, Oleg, and Dmitry Mukhin, 2019, Exchange rate disconnect in general equilibrium, NBER Working Paper wp23401.

Karolyi, G Andrew, and René M Stulz, 2003, Are financial assets priced locally or globally?, in George Constantinides, Milton Harris, and René Stulz, eds., Handbook of the Economics of Finance (Elsevier).

Lahiri, Soumendra N, 1999, Theoretical comparisons of block bootstrap methods, Annals of Statistics 27, 386-404.

Lewis, Karen K, 2011, Global asset pricing, Annual Review of Financial Economics 3, 435-466.

Lucas, Robert E Jr, and Nancy L Stokey, 1983, Optimal fiscal and monetary policy in an economy without capital, Journal of Monetary Economics 12, 55-93.

Lustig, Hanno, Nikolai Roussanov, and Adrien Verdelhan, 2011, Common risk factors in currency markets, Review of Financial Studies 24, 3731-3777.

Lustig, Hanno, Christopher Sleet, and Şevin Yeltekin, 2008, Fiscal hedging with nominal assets, Journal of Monetary Economics 55, 710-727.

Lustig, Hanno, and Adrien Verdelhan, 2007, The cross section of foreign currency risk premia and consumption growth risk, American Economic Review 97, 89-117.

Maddala, G S, 2001, Introduction to Econometrics (Wiley).

Maggiori, Matteo, Brent Neiman, and Jesse Schreger, 2019, International currencies and capital allocation, Journal of Political Economy forthcoming.

Missale, Alessandro, and Olivier Jean Blanchard, 1994, The debt burden and debt maturity, American Economic Review 84, 309-319.

Morelli, Juan M, Pablo Ottonello, and Diego J Perez, 2019, Global banks and systemic debt crises, New York University and University of Michigan .

Ottonello, Pablo, and Diego Perez, 2019, The currency composition of sovereign debt, American Economic Journal: Macroeconomics 11.

Pavlova, Anna, and Roberto Rigobon, 2007, Asset prices and exchange rates, Review of Financial Studies 20, 1139-1180.

Reinhart, Carmen M, and Kenneth S Rogoff, 2004, The modern history of exchange rate arrangements: A reinterpretation, Quarterly Journal of Economics 119, 1-48.

$\mathrm{Xu}$, Nancy, 2019, Global risk aversion and international return comovements, Working Paper, Boston College . 